\title{
Meta-Analysis: Exercise Therapy for Nonspecific Low Back Pain
}

Jill A. Hayden, DC; Maurits W. van Tulder, PhD; Antti V. Malmivaara, MD, PhD; and Bart W. Koes, PhD

Background: Exercise therapy is widely used as an intervention in low back pain.

Objective: To evaluate the effectiveness of exercise therapy in adult nonspecific acute, subacute, and chronic low back pain versus no treatment and other conservative treatments.

Data Sources: MEDLINE, EMBASE, Psychlnfo, CINAHL, and Cochrane Library databases to October 2004; citation searches and bibliographic reviews of previous systematic reviews.

Study Selection: Randomized, controlled trials evaluating exercise therapy for adult nonspecific low back pain and measuring pain, function, return to work or absenteeism, and global improvement outcomes.

Data Extraction: Two reviewers independently selected studies and extracted data on study characteristics, quality, and outcomes at short-, intermediate-, and long-term follow-up.

Data Synthesis: 61 randomized, controlled trials (6390 participants) met inclusion criteria: acute (11 trials), subacute (6 trials), and chronic (43 trials) low back pain (1 trial was unclear). Evidence suggests that exercise therapy is effective in chronic back pain relative to comparisons at all follow-up periods. Pooled mean improvement (of 100 points) was 7.3 points ( $95 \% \mathrm{Cl}, 3.7$ to 10.9 points) for pain and 2.5 points ( $\mathrm{Cl}, 1.0$ to 3.9 points) for function at earliest follow-up. In studies investigating patients (people seeking care for back pain), mean improvement was 13.3 points $(\mathrm{Cl}, 5.5$ to 21.1 points) for pain and 6.9 points $(\mathrm{Cl}, 2.2$ to 11.7 points) for function, compared with studies where some participants had been recruited from a general population (for example, with advertisements). Some evidence suggests effectiveness of a graded-activity exercise program in subacute low back pain in occupational settings, although the evidence for other types of exercise therapy in other populations is inconsistent. In acute low back pain, exercise therapy and other programs were equally effective (pain, 0.03 point $[\mathrm{Cl},-1.3$ to 1.4 points]).

Limitations: Limitations of the literature, including low-quality studies with heterogeneous outcome measures inconsistent and poor reporting, and possibility of publication bias.

Conclusions: Exercise therapy seems to be slightly effective at decreasing pain and improving function in adults with chronic low back pain, particularly in health care populations. In subacute low back pain populations, some evidence suggests that a gradedactivity program improves absenteeism outcomes, although evidence for other types of exercise is unclear. In acute low back pain populations, exercise therapy is as effective as either no treatment or other conservative treatments.

Ann Intern Med. 2005;142:765-775.

For author affiliations, see end of text.

www.annals.org included in our review. An updated review on this topic is needed. Cautious use of quantitative meta-analysis for direct and indirect comparisons in appropriate subgroups will be informative to synthesize this literature.

We aimed to assess the effectiveness of exercise therapy for reducing pain and disability in adults with nonspecific acute, subacute, and chronic low back pain compared with no treatment (including placebo and sham treatment) and other conservative treatments.

\section{Methods}

We searched the electronic databases MEDLINE and EMBASE (up to October 2004), PsychInfo and CINAHL (1999 to October 2004), and the Cochrane Central Reg-

See also:

Print

Editors' Notes . . . . . . . . . . . . . . . . . . . . . . 766

Related article. . . . . . . . . . . . . . . . . . . . . 776

Summary for Patients. . . . . . . . . . . . . . . . . . I-71

Web-Only

Appendix Tables

Conversion of figures and tables into slides 


\section{Context}

Many experts recommend exercise therapy for nonspecific low back pain.

\section{Contribution}

This meta-analysis summarizes data from 61 randomized, controlled trials that compared exercise therapy with placebo, no treatment, conservative management, or another exercise group. Exercise therapy decreased pain and improved physical function by modest amounts in adults with chronic low back pain. In adults with acute low back pain, exercise therapy, conservative management, and no treatment had similar effects on pain.

\section{Cautions}

Trials used various measures to assess pain and function, and many were small and of low quality.

-The Editors

ister of Controlled Trials (Issue 3, 2004). We conducted citation searches, screened cited references of exercise reviews, and contacted content experts for additional trials. We did not restrict the searches or inclusion criteria to any specific language. The complete search strategy is available on request.

We included published reports of completed randomized, controlled trials that included adults with acute $(<6$ weeks), subacute (6 to 12 weeks), or chronic ( $>12$ weeks) nonspecific low back pain. We excluded studies that involved individuals with low back pain caused by specific pathologies or conditions. Exercise therapy was defined as "a series of specific movements with the aim of training or developing the body by a routine practice or as physical training to promote good physical health" (6). We included studies that compared exercise therapy with no treatment or placebo treatment, other conservative therapy, or another exercise group.

Outcomes of interest were self-reported pain intensity, condition-specific physical functioning and global improvement, and return to work or absenteeism. We abstracted outcome assessment data for 3 time periods: shortterm (post-treatment assessment closest to 6 weeks after randomization but not longer than 12 weeks), intermediate (6 months), and long-term ( $\geq 12$ months) follow-up.

We followed a standard protocol for study selection and data abstraction (8). Two reviewers independently assessed study eligibility, data extraction, trial quality, and clinical relevance. We used consensus and a third reviewer, if necessary, to resolve disagreements. We extracted population characteristics (patient population source or setting, study inclusion criteria, duration of low back pain episode, and age of patients), intervention characteristics (description and types of exercise therapy, duration and number of treatment sessions, intervention delivery type, and co-inter- ventions), outcome data, and overall conclusions about the effectiveness of the exercises onto pretested standardized forms. Assessment of quality included appropriate randomization, adequate concealment of treatment allocation, adequacy of follow-up, and outcome assessment blinding (9). We defined high-quality studies as those that met all key quality criteria. We assessed clinical relevance of each trial with 4 items: participants described in detail to assess clinical comparability, interventions and treatment settings adequately described to allow repetition, clinically relevant outcomes measured and reported, and probability that treatment benefits are worth potential harms. Reviewers were not blinded to authors, institution, or journal of publication because of feasibility and because they were familiar with most of the literature. We contacted authors of published trials to clarify or provide additional information if the study provided insufficient information.

\section{Statistical Analysis}

We discussed the analyses of study results with clinical content experts. We synthesized the earliest outcomes provided for acute, subacute, and chronic low back pain, comparing exercise with no treatment and with other conservative treatment and overall for short-, intermediate-, and long-term follow-up periods. Because of important gaps in the reporting of return-to-work or absenteeism data and global assessment, quantitative analyses were only possible for pain and functioning outcomes. In the low back pain literature, studies used several outcome measures to assess the constructs of pain intensity (for example, a $10-\mathrm{mm}$ or $100-\mathrm{mm}$ visual analogue scale [VAS] or 0 - to 10-point numerical rating scale) (see recent review by von Korff and colleagues [10]) and condition-specific functioning (for example, the 24-point Roland Morris Disability Questionnaire or the 100-point Oswestry Disability Index) (see recent review by Kopec [11]). There are moderate to high correlations between the different measures of the 2 constructs. In our review, we rescaled individual trial outcomes for pain and functioning to 0 to 100 points. For example, we rescaled a VAS pain score $( \pm S D)$ of 5.1 points \pm 2.3 points out of 10 points to 51 points \pm 23 points out of 100 points, where positive mean effect sizes indicated improvement (that is, decreased pain and decreased functional limitations). Rescaling is common (11), and it facilitates comparison and interpretability of the syntheses. On the basis of current literature on minimal clinically important differences, we considered a 20-point (of 100 points) improvement in pain (12) and 10-point (of 100 points) improvement in functioning outcomes (13) to be clinically important. We considered differences to be statistically significant at the 5\% level. We assessed the adequacy of sample size to detect these differences in each trial by assuming a power of $90 \%$.

To be consistent with the previous review and to allow for more thorough use of available data, we used both a qualitative rating system and quantitative meta-analyses. 
We conducted the latter by pooling weighted mean differences with random-effects models and data from at least 3 studies (14). We included exercise treatment groups from included trials in the syntheses if they had an independent no-treatment or other-conservative-treatment comparison group. This requirement appropriately meant that we excluded studies with no comparison group (that is, trials that contrasted several exercise therapy groups only) and we did not double-count comparison groups in the metaanalyses. This latter criterion is necessary to avoid correlation in effect sizes resulting from the use of repeated comparison data. We extracted data on means or median follow-up outcomes for study groups. To maximize the available data, we imputed missing variance scores by using the mean variance from studies with similar duration. We conducted sensitivity analyses to assess the effect of excluding studies that reported median values and did not adequately present variance scores. We assessed statistical heterogeneity by using $\mathrm{I}^{2}$ statistics and $95 \%$ CIs (15). We evaluated publication bias with the Egger test and funnel plots (16).

We based qualitative assessment of results on primary outcome measures and considered the methodologic quality and the reviewers' overall conclusions for each exercise therapy group. We included exercise therapy groups in the qualitative synthesis if the trial included a no-treatment or other-conservative-treatment comparison group. Two reviewers independently rated the findings for each exercise therapy group. We considered studies to provide evidence of effectiveness if statistically significant improvement was observed in at least 1 key outcome in favor of the exercise group and clinically important improvement was observed within or between groups. We considered studies to provide evidence that the exercise therapy was ineffective if the comparison group statistically significantly improved and the exercise group did not statistically significantly improve. We rated studies as neutral if results were not statistically and clinically significant and as unclear if data were insufficient. We used a consensus process to examine patterns in trial results. Levels of evidence were strong (consistent findings in several high-quality trials), moderate (consistent findings in several low-quality trials or 1 highquality trial), limited (1 low-quality trial), conflicting (inconsistent findings in several trials), or none (no randomized trials available). We defined consistent findings as $75 \%$ or more trials (66\% in sensitivity analysis) showing similar results.

Further analyses explored heterogeneity due to studylevel variables, such as population source and study quality. We characterized the population sources as health care (primary, secondary, or tertiary care centers), occupational (patients presenting to occupational health care facilities or personnel in compensatory situations), or from a general or mixed population (for example, including individuals recruited by newspaper advertisements) to differentiate the studies with patients in typical treatment settings (health
Figure 1. Flow diagram of systematic review inclusion or exclusion.

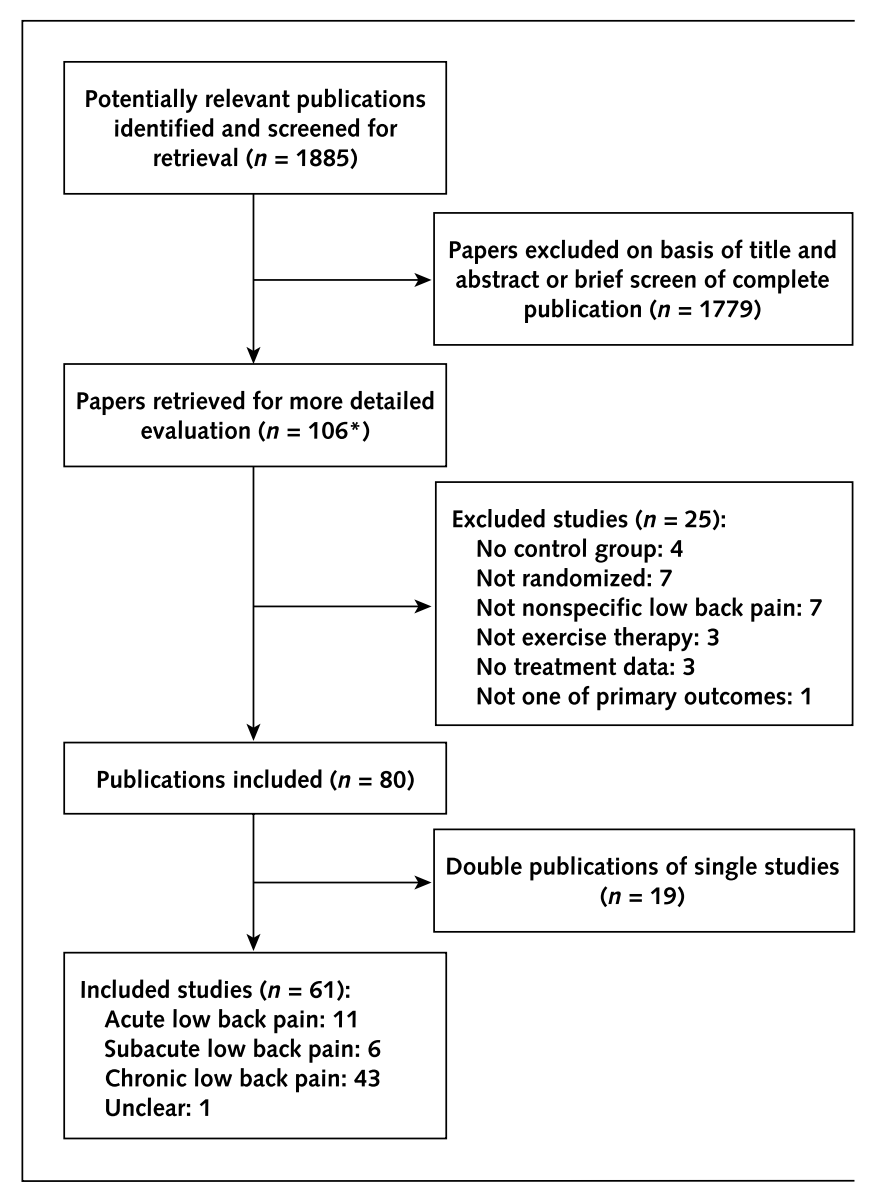

care and occupational) from those including individuals with low back pain who may not normally present for treatment. We compared outcomes for subgroups of studies conducted in these populations (17). We assessed the effect of study quality on effect sizes by using subgroup analysis.

We used SAS for Windows, version 8.0 (SAS Institute, Inc., Cary, North Carolina) (for descriptive); Stata, version 8.0 (Stata Corp., College Station, Texas) (for publication bias); and Review Manager 4.2 (Cochrane Collaboration, Oxford, United Kingdom) for analyses.

\section{Role of Funding Sources}

The personal funding sources for an author, the Canadian Institutes of Health Research (postdoctoral fellowship) and the Canadian Chiropractic Research Foundation, had no role in the collection, analysis, or interpretation of the data or in the decision to submit the manuscript for publication.

\section{RESULTS}

\section{Study Characteristics}

Figure 1 shows details of included and excluded studies. In van Tulder and colleagues' review (1), which as-

$$
3 \text { May 2005|Annals of Internal Medicine } \mid \text { Volume } 142 \bullet \text { Number } 9 \mid 767
$$


REVIEW $\mid$ Exercise Therapy for Low Back Pain

Table. Description of the Included Studies*

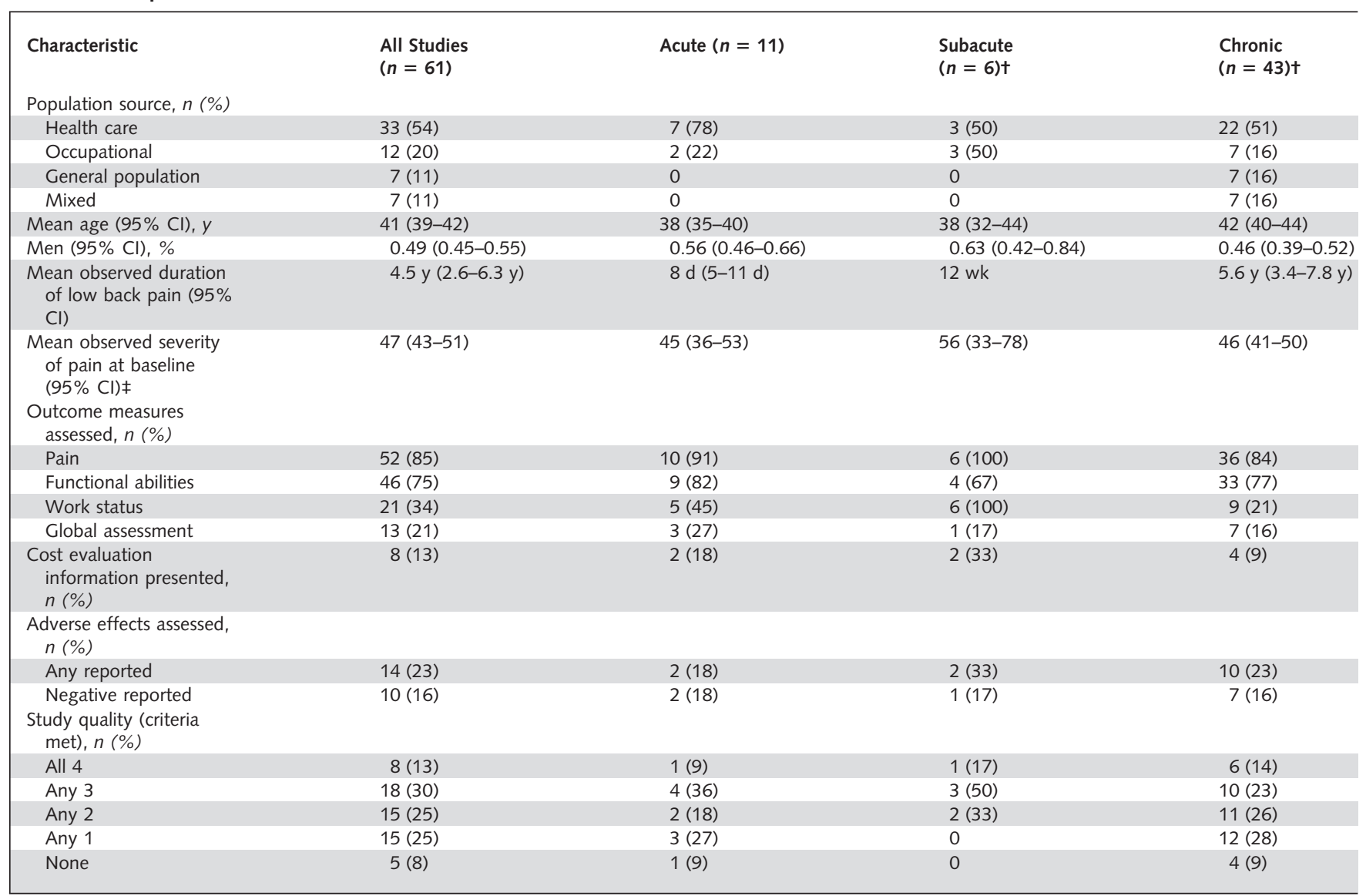

* Discrepancies between sum and denominator reflect missing information.

† Study samples were classified according to most appropriate category on the basis of inclusion criteria and reported duration. Thirteen studies included patients with mixed duration of low back pain.

¥ Based on 100-point scale.

sessed 10 quality items, including the 4 key items investigated in our review, the reviewers disagreed on 122 of the 351 quality assessment scores (35\%). Disagreements were resolved by consensus in most cases, and a third reviewer only had to make a final decision twice. In the new trials included in our current review, the reviewers disagreed on 19 of the 124 key item scores (15\%), resulting in a $\kappa$ score of 0.76 (95\% CI, 0.67 to 0.86 ), indicating high agreement. For our review, we resolved disagreements by consensus in all but 2 cases, when we needed a third reviewer to reach a decision.

The Table contains the descriptive summary and characteristics of the 61 studies included (18-95), and Appendix Table 1 (available at www.annals.org) presents a complete description of these studies. Only 8 studies scored "positive" on all key validity criteria (18-31). On the basis of information in the published report, we initially rated $37(15 \%)$ of the key quality items assessed as unclear (the most common item with insufficient description was "adequate concealment of treatment allocation"). Contacting the authors of the trials supplemented this information, modifying $14 \%$ of the criteria for which responses were received. Assessment of clinical relevance found that many of the trial publications supplied inadequate information. Ninety percent of studies adequately described the study population, but only 54\% adequately described the exercise intervention. Seventy percent of the trials adequately reported relevant outcomes. Few studies reported on adverse events (16 studies [26\%]). Twelve studies reported mild negative reactions to the exercise program, such as increased low back pain and muscle soreness, in some patients. We could not assess the treatment benefit-to-harm ratio because of limitations of reporting. Appendix Table 2 (available at www.annals.org) presents the pain and function outcomes for each trial. The VAS score (out of 100 points) was the most common outcome measure used to assess pain across studies (22 studies), and $83 \%$ of studies reporting pain used a VAS score of 100 points, a VAS score of 10 points, a numerical rating scale score of 100 points, or a numerical rating scale score of 10 points. Other pain outcome measures included the McGill pain questionnaire (4 studies), a 5- or 9-point Likert pain scale (1 study), the Aberdeen pain scale (1 study), and the West Haven Yale questionnaire (1 study). The most common functional limitation outcome measures, used in $59 \%$ of trials, were the Oswestry Disability Index (15 studies) and the Roland 
Morris disability questionnaire (12 studies). Other functional measures included VAS function scale (4 studies), activities of daily living scale (3 studies), sickness impact profile (2 studies), Quebec disability index (2 studies), Manniche low back rating scale (2 studies), and 5 additional scales that were each used in single trials. The mean follow-up times for the short-, intermediate-, and longterm follow-up periods were 6.3 weeks (CI, 5.3 to 7.3 weeks), 21.0 weeks (CI, 18.4 to 23.6 weeks), and 53.6 weeks (CI, 48.7 to 58.6 weeks), respectively.

\section{Effectiveness}

\section{Acute Low Back Pain Populations}

Ten of 11 trials involving 1192 adults with acute low back pain had nonexercise comparisons. These trials provided conflicting evidence: 1 high-quality trial conducted in an occupational setting found mobilizing home exercises to be less effective than usual care (25), and 1 low-quality trial conducted in a health care setting found that a therapist-delivered endurance program improved short-term functioning more than no treatment (62). Of the remaining 8 low-quality trials, 6 trials found no statistically significant or clinically important differences between exercise therapy and usual care or no treatment and the results of 2 trials were unclear. We most commonly rated these trials as low-quality because of inadequate assessor blinding. One trial (80) had inadequate power to detect clinically important differences in pain, and 5 trials $(68,76,80,81,95)$ had inadequate power to detect clinically important differences in functioning.

The pooled analysis of trials with adequate numerical data did not show a difference in short-term pain relief between exercise therapy and no treatment ( 3 trials), with an effect of -0.59 point (CI, -12.69 to 11.51 points) out of 100 points. There was no difference at earliest follow-up in pain relief with exercise therapy when compared with other conservative treatments ( 7 trials) $(0.31$ point [CI, -0.10 to 0.72 point]) (compared with all comparisons [10 trials], 0.03 point [CI, -1.34 to 1.40 points]). Similarly, exercise therapy did not have a statistically significantly positive effect on functional outcomes. Outcomes show similar trends at the 3 follow-up periods in this population (Figure 2).

\section{Subacute Low Back Pain Populations}

In 6 studies involving 881 individuals with subacute low back pain, 7 exercise groups had nonexercise comparisons. One high-quality and 1 low-quality trial found reduced absenteeism outcomes with a graded-activity intervention in the workplace compared with usual care (22, 90). This provides moderate evidence of effectiveness of a graded-activity exercise program in subacute low back pain in occupational settings. One low-quality trial found improved functioning over usual care with an exercise program combined with behavioral therapy (47). We rated 2 trials with inadequate assessor blinding as neutral, although they were adequately powered to detect clinically important differences in at least 1 primary outcome $(35,91)$. The results of 1 trial were unclear (64). The evidence is conflicting about the effectiveness of other types of exercise therapy in subacute low back pain compared with other treatments.

Meta-analysis of pain outcomes at the earliest followup, including 5 studies with available data, resulted in a pooled weighted mean difference in pain score of 1.89 points (CI, -1.13 to 4.91 points) relative to any comparison. The pooled analysis of 4 trials presenting data on functional outcomes found a mean difference of 1.07 points (CI, -3.18 to 5.32 points) relative to other comparisons. Evidence is insufficient to support or refute the effectiveness of exercise therapy in subacute low back pain for reducing pain intensity and improving function. Figure 2 shows the results for short- and intermediate-term follow-up periods in the subacute low back pain population.

\section{Chronic Low Back Pain Populations}

In 43 trials including 3907 individuals with chronic low back pain, 33 exercise groups had nonexercise comparisons. These trials provide strong evidence that exercise therapy is at least as effective as other conservative interventions and conflicting evidence that exercise therapy is more effective than other treatments for chronic low back pain. Two exercise groups in high-quality studies and 9 groups in low-quality studies found that exercise was more effective than comparison treatments. These studies, mostly conducted in health care settings, commonly used exercise programs that were individually designed and delivered (as opposed to independent home exercises) (19, $43,48,57,75,88)$. The exercise programs commonly included strengthening or trunk-stabilizing exercises $(19,44$, $48,50,75,88)$. Conservative care was often added to exercise therapy, including behavioral and manual therapy, advice to stay active, and education. One low-quality trial found that a group-delivered aerobics and strengthening exercise program resulted in less improvement in pain and function outcomes than behavioral therapy (57). Of the remaining trials, 14 (2 high-quality and 12 low-quality) found no statistically significant or clinically important differences between exercise therapy and other conservative treatments. Four of these trials were inadequately powered to detect clinically important differences on at least 1 outcome $(56,82,89,92)$. We commonly rated trials as lowquality because of inadequate assessor blinding.

Meta-analysis of pain outcomes at the earliest follow-up included 23 exercise groups with an independent comparison and adequate data. Synthesis resulted in a pooled weighted mean improvement of 10.2 points (CI, 1.31 to 19.09 points) for exercise therapy compared with no treatment and 5.93 points (CI, 2.21 to 9.65 points) for exercise therapy compared with other conservative treatment (compared with all comparisons, 7.29 points [CI, 
REVIEW $\mid$ Exercise Therapy for Low Back Pain

Figure 2. Results of meta-analyses of exercise versus any comparison for acute (top), subacute (middle), and chronic low back pain populations (bottom) and pain and function outcomes at short-, intermediate-, and long-term follow-ups.

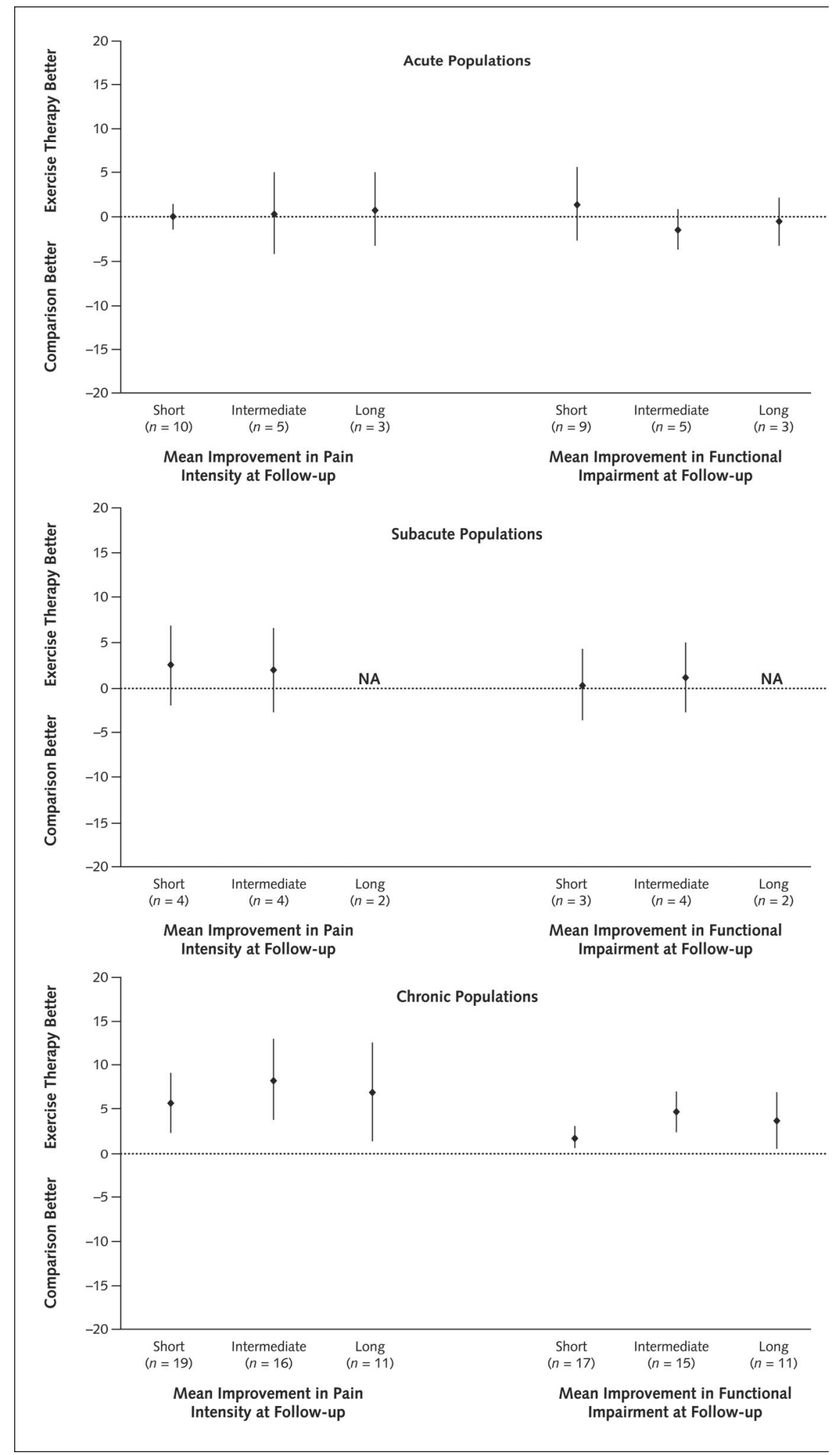

Results shown are mean change on a 100-point scale (lines are $95 \%$ CIs). Clinically important improvement is considered to be 20 of 100 points for pain intensity and 10 of 100 points for functional impairment. 
Figure 3. Meta-analyses for population source subgroups in chronic low back pain populations: health care, occupational, and general or mixed populations at earliest follow-up.

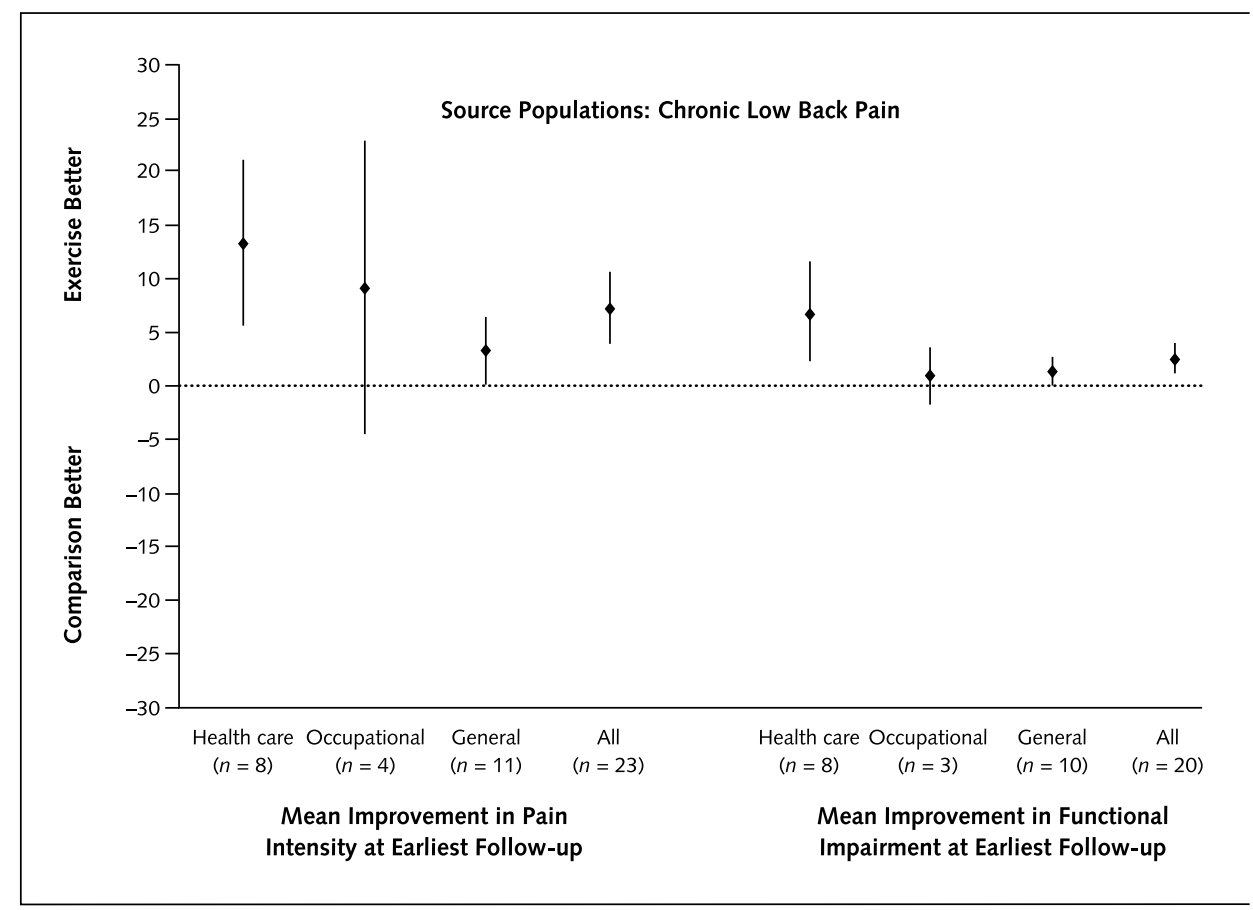

Results shown are mean change on a 100-point scale (lines are 95\% CIs). Clinically important improvement is considered to be 20 of 100 points for pain intensity and 10 of 100 points for functional impairment.

3.67 to 10.91 points]). At the earliest follow-up, smaller improvements occurred in functional outcomes with an observed mean positive effect of 3.00 points $(\mathrm{CI},-0.53$ to 6.48 points) compared with no treatment and 2.37 points (CI, 0.74 to 4.0 points) compared with other conservative treatment (compared with all comparisons, 2.50 points [CI, 1.04 to 3.94 points]). Results considering different follow-up periods were similar for pain and functional outcomes (Figure 2). Egger test results suggested publication bias among studies in chronic low back pain populations $(P=0.015)$; funnel plot analysis showed that this was likely because 3 studies demonstrated highly variable, large positive effects $(56,60,63)$.

Sensitivity analyses for qualitative syntheses did not affect the conclusions. We conducted meta-analyses, excluding the results of studies that presented data as median scores $(21,57,58,62,89)$ or did not provide variance scores $(40,41,63,68)$. This did not affect the pooled results for acute and subacute low back pain populations. In chronic low back pain populations, our sensitivity analysis resulted in lower, although still statistically significantly improved, pooled effect sizes. Complete results of all analyses are available on request.

\section{Further Analyses}

We conducted analyses on studies from acute, subacute, and chronic low back pain populations to assess the effect of study level variables. Tests of statistical heteroge- neity of pain outcomes found that $57 \%$ (CI, $12 \%$ to $79 \%$ ), $37 \%$ (CI, $0 \%$ to $76 \%$ ), and $81 \%$ (CI, $72 \%$ to $87 \%$ ) of the heterogeneity for acute, subacute, and chronic low back pain populations, respectively, was not due to chance. Function outcomes showed values of $80 \%$ (CI, $63 \%$ to $89 \%$ ), $47 \%$ (CI, $0 \%$ to $82 \%$ ), and $52 \%$ (CI, $19 \%$ to $71 \%$ ), respectively. To account for heterogeneity, we used random-effects models and investigated clinically relevant subgroups of studies. A complete exploration of intervention heterogeneity is included in our accompanying paper (96).

Indirect subgroup comparisons using qualitative synthesis and meta-analysis found that trials examining health care study populations observed higher mean improvements in functioning and pain over their comparison groups than trials examining occupational or general populations (Figure 3). In chronic populations, mean improvements in health care settings were 13.3 points (CI, 5.5 to 21.1 points) for pain and 6.9 points (CI, 2.2 to 11.7 points) for function outcomes. The adjusted differences between studies with different source populations found statistically significantly greater improvement in outcomes in health care populations compared with studies from general population or mixed populations, with a mean improvement of 9.96 points (CI, 1.6 to 18.4 points) in pain outcomes and 5.52 points (CI, 0.6 to 10.4 points) in functioning.

We conducted meta-analyses on the subgroup of high- 
quality trials. The observed effectiveness of exercise therapy decreased and only remained statistically significant for pain outcomes in the chronic low back pain population.

\section{Discussion}

We believe that our review is the most up-to-date assessment of the effectiveness of exercise therapy in key population subgroups. For the most part, results were similar by using either a qualitative rating system or meta-analysis. We draw the following conclusions, which provide useful information for primary care clinicians to help guide their patient management and referral practices.

1. In acute low back pain, evidence suggests that exercises are not more effective than other conservative treatments. Meta-analysis showed no advantage over no treatment for pain and functional outcomes over the short- or long-term follow-up.

2. Some evidence suggests effectiveness of a gradedactivity exercise program in subacute low back pain in occupational settings. The effectiveness for other types of exercise therapy in other populations is unclear.

3. In chronic low back pain, evidence strongly suggests that exercise is at least as effective as other conservative treatments. Individually designed strengthening or stabilizing programs seem to be effective in health care settings. Meta-analysis found functional outcomes statistically significantly improved; however, the effects were very small, with less than a 3-point (out of 100) difference between the exercise and comparison groups at earliest follow-up. Pain outcomes also statistically significantly improved in groups receiving exercises relative to other comparisons, with a mean of approximately 7 points. Effects were similar over longer follow-up, although CIs increased. Mean improvements in pain and functioning may be clinically meaningful in studies from health care populations in which improvements were statistically significantly greater than those observed in studies from general or mixed populations.

Our study has several strengths and also some limitations. Many randomized, controlled trials informed our study, and we collected the data in a systematic way within the framework of the Cochrane Collaboration, suggesting that our synthesis represents the current state of the literature. However, limitations in the quality and reporting of the trials are notable. We rated only a few studies as highquality, and this may have led to an overestimation of effect. Also, many studies lacked information to assess quality and clinical relevance. Contacting the authors of the trials provided data that were missing, emphasizing the importance and usefulness of this practice. The only outcome measure used in most studies was pain intensity (in $85 \%$ ), which limits the ability to report on other important outcomes. In 1998, a group of back pain researchers recommended standardized use of outcome measures in back pain research, suggesting a minimum of pain, functional status, and general health measures (97). The lack of consistency observed is disappointing, as is the fact that only three quarters of the studies in our review included a measure of functional status and only $15 \%$ included a measure of general health. Journals in the field of back pain should adopt reporting guidelines (98) and, even more important, use them in their review process to improve the quality of future reports of trials in this field. We found potential publication bias in studies in chronic low back pain, which may have resulted in an overestimation of the effectiveness of exercise therapy in this population. Initiatives in other fields to register randomized, controlled trials will also be important in low back pain research. We used both qualitative and quantitative synthesis strategies in our review, which were informative. Qualitative synthesis methods facilitate the inclusion of results from trials that inadequately report outcomes. This is particularly useful when only some studies are available, for example, in subacute populations in our review. However, the qualitative synthesis was more challenging in assessing the evidence in chronic populations, where many studies were available.

Our meta-analysis found no evidence that exercise therapy is more effective than no treatment in improving outcomes in acute low back pain. This finding is consistent with the original Cochrane review on this topic (1) and other systematic reviews $(2,6,7)$. However, we emphasize that exercise therapy is not the same as advice to stay active, which is a recommended treatment strategy in acute populations $(6,99)$. In the subacute population, which was not considered separately in the original Cochrane review, 6 trials were available. In a recent systematic review of various conservative interventions, Pengel and colleagues (100) concluded that there was an important gap in evidence for these interventions in treating subacute low back pain. In our review, 2 trials $(22,90)$ found reduced absenteeism outcomes with a graded-activity intervention compared with usual care, although there continues to be uncertainty about other types of exercises and in health care populations. We also recommend more clear definitions and further high-quality research of exercise therapy in this population. Finally, our positive findings in chronic low back pain populations reflect the conclusions of earlier reviews $(2,6,7)$. Our quantitative analysis estimates the average treatment effect and its uncertainty, highlighting an overall small treatment benefit. Our finding of greater improvement in trials investigating health care populations is important. Future intervention studies should be conducted in populations that are seeking care and therefore best represent low back pain patients. We do not recommend further research on the effectiveness of general exercise therapy interventions in chronic low back pain. Trials should investigate specific exercise intervention strategies in welldefined populations of patients with low back pain (96).

Evidence from randomized, controlled trials demonstrates that exercise therapy effectively reduces pain and functional limitations in the treatment of chronic low back 
pain, although cautious interpretation is required due to limitations in this literature. Overall, mean improvements in outcomes across all research settings are small, although statistically significant, compared with other conservative treatment options. Clinically important improvements are more likely in health care settings. Some evidence suggests effectiveness of a graded-activity exercise program in subacute low back pain in occupational settings, although the evidence for other types of exercise therapy in other populations is unclear and further research is required. This literature suggests exercise therapy is as effective as either no treatment or other conservative treatments for acute low back pain.

From Institute for Work \& Health and University of Toronto, Toronto, Ontario, Canada; Institute for Research in Extramural Medicine, VU University Medical Center, Amsterdam, the Netherlands; Finnish Office for Health Care Technology Assessment, National Research and Development Centre for Welfare and Health, Helsinki, Finland; and Erasmus University Medical Center, Rotterdam, the Netherlands.

Acknowledgments: The authors thank Drs. Jens Ivar Brox and Jan Lonn and Mr. Arne Naess for their assistance with the quality assessment and data extraction from non-English-language studies; the Physiotherapy "Educational Influentials" from the Institute for Work \& Health for their guidance with syntheses; Emma Irvin, medical librarian at the Institute for Work \& Health, for her assistance with the search strategy; Victoria Pennick for her assistance with editing; and Rosmin Esmail for her contribution to the original version of this review.

Grant Support: No external project funding was obtained for this study. Dr. Hayden is funded by a postdoctoral fellowship award from the Canadian Institutes of Health Research and Canadian Chiropractic Research Foundation.

\section{Potential Financial Conflicts of Interest: None disclosed.}

Corresponding Author: Jill A. Hayden, DC, Institute for Work \& Health, 481 University Avenue, Suite 800, 8th Floor, Toronto, Ontario M5G 2E9, Canada; e-mail, jhayden@iwh.on.ca.

Current author addresses are available at www.annals.org.

\section{References}

1. van Tulder M, Malmivaara A, Esmail R, Koes B. Exercise therapy for low back pain: a systematic review within the framework of the cochrane collaboration back review group. Spine. 2000;25:2784-96. [PMID: 11064524]

2. Hilde G, Bo K. Effect of exercise in the treatment of chronic low back pain: a systematic review emphasising type and dose of exercise. Physical Therapy Reviews. 1998;3:107-17.

3. Liddle SD, Baxter GD, Gracey JH. Exercise and chronic low back pain: what works? Pain. 2004;107:176-90. [PMID: 14715404]

4. Kool J, de Bie R, Oesch P, Knüsel O, van den Brandt P, Bachmann S. Exercise reduces sick leave in patients with non-acute non-specific low back pain: a meta-analysis. J Rehabil Med. 2004;36:49-62. [PMID: 15180219]

5. Ernst E, Canter PH. The Alexander technique: a systematic review of controlled clinical trials. Forsch Komplementarmed Klass Naturheilkd. 2003;10: 325-9. [PMID: 14707481]

6. Abenhaim L, Rossignol M, Valat JP, Nordin M, Avouac B, Blotman F, et al. The role of activity in the therapeutic management of back pain. Report of the International Paris Task Force on Back Pain. Spine. 2000;25:1S-33S. [PMID: 10707404]
7. Philadelphia Panel evidence-based clinical practice guidelines on selected rehabilitation interventions for low back pain. Phys Ther. 2001;81:1641-74. [PMID: 11589642]

8. van Tulder M, Furlan A, Bombardier C, Bouter L. Updated method guidelines for systematic reviews in the cochrane collaboration back review group. Spine. 2003;28:1290-9. [PMID: 12811274]

9. Jadad AR, Moore RA, Carroll D, Jenkinson C, Reynolds DJ, Gavaghan DJ, et al. Assessing the quality of reports of randomized clinical trials: is blinding necessary? Control Clin Trials. 1996;17:1-12. [PMID: 8721797]

10. Von Korff M, Jensen MP, Karoly P. Assessing global pain severity by selfreport in clinical and health services research. Spine. 2000;25:3140-51. [PMID: 11124730]

11. Kopec JA. Measuring functional outcomes in persons with back pain: a review of back-specific questionnaires. Spine. 2000;25:3110-4. [PMID: 11124726] 12. Salaffi F, Stancati A, Silvestri CA, Ciapetti A, Grassi W. Minimal clinically important changes in chronic musculoskeletal pain intensity measured on a numerical rating scale. Eur J Pain. 2004;8:283-91. [PMID: 15207508]

13. Bombardier C, Hayden J, Beaton DE. Minimal clinically important difference. Low back pain: outcome measures. J Rheumatol. 2001;28:431-8. [PMID: 11246692]

14. DerSimonian R, Laird N. Meta-analysis in clinical trials. Control Clin Trials. 1986;7:177-88. [PMID: 3802833]

15. Higgins JP, Thompson SG. Quantifying heterogeneity in a meta-analysis. Stat Med. 2002;21:1539-58. [PMID: 12111919]

16. Egger M, Davey Smith G, Schneider M, Minder C. Bias in meta-analysis detected by a simple, graphical test. BMJ. 1997;315:629-34. [PMID: 9310563] 17. Song F, Altman DG, Glenny AM, Deeks JJ. Validity of indirect comparison for estimating efficacy of competing interventions: empirical evidence from published meta-analyses. BMJ. 2003;326:472. [PMID: 12609941]

18. Deyo RA, Walsh NE, Martin DC, Schoenfeld LS, Ramamurthy S. A controlled trial of transcutaneous electrical nerve stimulation (TENS) and exercise for chronic low back pain. N Engl J Med. 1990;322:1627-34. [PMID: 2140432] 19. Frost H, Klaber Moffett JA, Moser JS, Fairbank JC. Randomised controlled trial for evaluation of fitness programme for patients with chronic low back pain. BMJ. 1995;310:151-4. [PMID: 7833752]

20. Frost H, Lamb SE, Klaber Moffett JA, Fairbank JC, Moser JS. A fitness programme for patients with chronic low back pain: 2-year follow-up of a randomised controlled trial. Pain. 1998;75:273-9. [PMID: 9583763]

21. Hansen FR, Bendix T, Skov P, Jensen CV, Kristensen JH, Krohn L, et al. Intensive, dynamic back-muscle exercises, conventional physiotherapy, or placebo-control treatment of low-back pain. A randomized, observer-blind trial. Spine. 1993;18:98-108. [PMID: 8434332]

22. Lindström I, Ohlund C, Eek C, Wallin L, Peterson LE, Fordyce WE, et al. The effect of graded activity on patients with subacute low back pain: a randomized prospective clinical study with an operant-conditioning behavioral approach. Phys Ther. 1992;72:279-90; discussion 291-3. [PMID: 1533941]

23. Lindström I. A successful intervention program for patients with subacute low back pain [Dissertation]. Göteborg, Sweden: Göteborg University; 1994.

24. Lindström I, Ohlund C, Eek C, Wallin L, Peterson LE, Nachemson A. Mobility, strength, and fitness after a graded activity program for patients with subacute low back pain. A randomized prospective clinical study with a behavioral therapy approach. Spine. 1992;17:641-52. [PMID: 1385658]

25. Malmivaara A, Häkkinen U, Aro T, Heinrichs ML, Koskenniemi L, Kuosma E, et al. The treatment of acute low back pain-bed rest, exercises, or ordinary activity? N Engl J Med. 1995;332:351-5. [PMID: 7823996]

26. Manniche C, Hesselsøe G, Bentzen L, Christensen I, Lundberg E. Clinical trial of intensive muscle training for chronic low back pain. Lancet. 1988;2: 1473-6. [PMID: 2904582]

27. Manniche C, Lundberg E, Christensen I, Bentzen L, Hesselsøe G. Intensive dynamic back exercises for chronic low back pain: a clinical trial. Pain. 1991;47: 53-63. [PMID: 1837606]

28. Mannion AF, Müntener M, Taimela S, Dvorak J. Comparison of three active therapies for chronic low back pain: results of a randomized clinical trial with one-year follow-up. Rheumatology (Oxford). 2001;40:772-8. [PMID: $11477282]$

29. Mannion AF, Müntener M, Taimela S, Dvorak J. A randomized clinical trial of three active therapies for chronic low back pain. Spine. 1999;24:2435-48. [PMID: 10626305]

30. Mannion AF, Junge A, Taimela S, Müntener M, Lorenzo K, Dvorak J. Active therapy for chronic low back pain: part 3. Factors influencing self-rated 
disability and its change following therapy. Spine. 2001;26:920-9. [PMID: 11317114]

31. Torstensen TA, Ljunggren AE, Meen HD, Odland E, Mowinckel P, Geijerstam S. Efficiency and costs of medical exercise therapy, conventional physiotherapy, and self-exercise in patients with chronic low back pain. A pragmatic, randomized, single-blinded, controlled trial with 1-year follow-up. Spine. 1998; 23:2616-24. [PMID: 9854761]

32. Aure OF, Nilsen JH, Vasseljen O. Manual therapy and exercise therapy in patients with chronic low back pain: a randomized, controlled trial with 1-year follow-up. Spine. 2003;28:525-31; discussion 531-2. [PMID: 12642755]

33. Bentsen $H$, Lindgärde F, Manthorpe R. The effect of dynamic strength back exercise and/or a home training program in 57-year-old women with chronic low back pain. Results of a prospective randomized study with a 3-year follow-up period. Spine. 1997;22:1494-500. [PMID: 9231969]

34. Bronfort G, Goldsmith CH, Nelson CF, Boline PD, Anderson AV. Trunk exercise combined with spinal manipulative or NSAID therapy for chronic low back pain: a randomized, observer-blinded clinical trial. J Manipulative Physiol Ther. 1996;19:570-82. [PMID: 8976475]

35. Cherkin DC, Deyo RA, Battié M, Street J, Barlow W. A comparison of physical therapy, chiropractic manipulation, and provision of an educational booklet for the treatment of patients with low back pain. N Engl J Med. 1998; 339:1021-9. [PMID: 9761803]

36. Elnaggar IM, Nordin M, Sheikhzadeh A, Parnianpour M, Kahanovitz N. Effects of spinal flexion and extension exercises on low-back pain and spinal mobility in chronic mechanical low-back pain patients. Spine. 1991;16:967-72. [PMID: 1835157]

37. Faas A, Chavannes AW, van Eijk JT, Gubbels JW. A randomized, placebocontrolled trial of exercise therapy in patients with acute low back pain. Spine. 1993;18:1388-95. [PMID: 8235809]

38. Faas A, van Eijk JT, Chavannes AW, Gubbels JW. A randomized trial of exercise therapy in patients with acute low back pain. Efficacy on sickness absence. Spine. 1995;20:941-7. [PMID: 7644960]

39. Glomsrød B, Lønn JH, Soukup MG, Bø K, Larsen S. "Active back school", prophylactic management for low back pain: three-year follow-up of a randomized, controlled trial. J Rehabil Med. 2001;33:26-30. [PMID: 11480466]

40. Hemmilä HM, Keinänen-Kiukaanniemi SM, Levoska S, Puska P. Does folk medicine work? A randomized clinical trial on patients with prolonged back pain. Arch Phys Med Rehabil. 1997;78:571-7. [PMID: 9196462]

41. Hemmilä HM, Keinänen-Kiukaanniemi SM, Levoska S, Puska P. Longterm effectiveness of bone-setting, light exercise therapy, and physiotherapy for prolonged back pain: a randomized controlled trial. J Manipulative Physiol Ther. 2002;25:99-104. [PMID: 11896377]

42. Hides JA, Jull GA, Richardson CA. Long-term effects of specific stabilizing exercises for first-episode low back pain. Spine. 2001;26:E243-8. [PMID: 11389408]

43. Hildebrandt VH, Proper KI, van den Berg R, Douwes M, van den Heuvel SG, van Buuren S. [Cesar therapy is temporarily more effective in patients with chronic low back pain than the standard treatment by family practitioner: randomized, controlled and blinded clinical trial with 1 year follow-up]. Ned Tijdschr Geneeskd. 2000;144:2258-64. [PMID: 11109471]

44. Kankaanpää M, Taimela S, Airaksinen O, Hänninen O. The efficacy of active rehabilitation in chronic low back pain. Effect on pain intensity, selfexperienced disability, and lumbar fatigability. Spine. 1999;24:1034-42. [PMID: 10332798]

45. Ljunggren AE, Weber H, Kogstad O, Thom E, Kirkesola G. Effect of exercise on sick leave due to low back pain. A randomized, comparative, longterm study. Spine. 1997;22:1610-6; discussion 1617. [PMID: 9253097]

46. Lønn JH, Glomsrød B, Soukup MG, Bø K, Larsen S. Active back school: prophylactic management for low back pain. A randomized, controlled, 1-year follow-up study. Spine. 1999;24:865-71. [PMID: 10327507]

47. Moffett JK, Torgerson D, Bell-Syer S, Jackson D, Llewlyn-Phillips H, Farrin A, et al. Randomised controlled trial of exercise for low back pain: clinical outcomes, costs, and preferences. BMJ. 1999;319:279-83. [PMID: 10426734] 48. Moseley L. Combined physiotherapy and education is efficacious for chronic low back pain. Aust J Physiother. 2002;48:297-302. [PMID: 12443524]

49. Petersen T, Kryger P, Ekdahl C, Olsen S, Jacobsen S. The effect of McKenzie therapy as compared with that of intensive strengthening training for the treatment of patients with subacute or chronic low back pain: a randomized controlled trial. Spine. 2002;27:1702-9. [PMID: 12195058]
50. Preyde M. Effectiveness of massage therapy for subacute low-back pain: a randomized controlled trial. CMAJ. 2000;162:1815-20. [PMID: 10906914] 51. Rittweger J, Just K, Kautzsch K, Reeg P, Felsenberg D. Treatment of chronic lower back pain with lumbar extension and whole-body vibration exercise: a randomized controlled trial. Spine. 2002;27:1829-34. [PMID: 12221343] 52. Soukup MG, Glomsröd B, Lönn JH, Bö K, Larsen S. The effect of a Mensendieck exercise program as secondary prophylaxis for recurrent low back pain. A randomized, controlled trial with 12-month follow-up. Spine. 1999;24: 1585-91; discussion 1592. [PMID: 10457579]

53. Soukup MG, Lönn J, Glomsröd B, Bö K, Larsen S. Exercises and education as secondary prevention for recurrent low back pain. Physiother Res Int. 2001;6: 27-39. [PMID: 11379254]

54. Stankovic R, Johnell O. Conservative treatment of acute low-back pain. A prospective randomized trial: McKenzie method of treatment versus patient education in "mini back school". Spine. 1990;15:120-3. [PMID: 2139241]

55. Stankovic R, Johnell O. Conservative treatment of acute low back pain. A 5-year follow-up study of two methods of treatment. Spine. 1995;20:469-72. [PMID: 7747231]

56. Alexandre NM, de Moraes MA, Corrêa Filho HR, Jorge SA. Evaluation of a program to reduce back pain in nursing personnel. Rev Saude Publica. 2001; 35:356-61. [PMID: 11600924]

57. Bendix AF, Bendix T, Ostenfeld S, Bush E, Andersen A. Active treatment programs for patients with chronic low back pain: a prospective, randomized, observer-blinded study. Eur Spine J. 1995;4:148-52. [PMID: 7552649]

58. Bendix AF, Bendix T, Labriola M, Boekgaard P. Functional restoration for chronic low back pain. Two-year follow-up of two randomized clinical trials. Spine. 1998;23:717-25. [PMID: 9549794]

59. Bendix AF, Bendix T, Lund C, Kirkbak S, Ostenfeld S. Comparison of three intensive programs for chronic low back pain patients: a prospective, randomized, observer-blinded study with one-year follow-up. Scand J Rehabil Med. 1997;29:81-9. [PMID: 9198257]

60. Bendix T, Bendix A, Labriola M, Haestrup C, Ebbehøj N. Functional restoration versus outpatient physical training in chronic low back pain: a randomized comparative study. Spine. 2000;25:2494-500. [PMID: 11013502]

61. Buswell J. Low back pain: a comparison of two treatment programmes. New Zealand Journal of Physiotherapy. 1982;10:13-7.

62. Chok B, Lee R, Latimer J, Tan SB. Endurance training of the trunk extensor muscles in people with subacute low back pain. Phys Ther. 1999;79:1032-42. [PMID: 10534796]

63. Dalichau S, Scheele K. [Effects of elastic lumbar belts on the effect of a muscle training program for patients with chronic back pain]. Z Orthop Ihre Grenzgeb. 2000;138:8-16. [PMID: 10730357]

64. Davies JE, Gibson T, Tester L. The value of exercises in the treatment of low back pain. Rheumatol Rehabil. 1979;18:243-7. [PMID: 160072]

65. Delitto A, Cibulka MT, Erhard RE, Bowling RW, Tenhula JA. Evidence for use of an extension-mobilization category in acute low back syndrome: a prescriptive validation pilot study. Phys Ther. 1993;73:216-22; discussion 223-8. [PMID: 8456141]

66. Descarreaux M, Normand MC, Laurencelle L, Dugas C. Evaluation of a specific home exercise program for low back pain. J Manipulative Physiol Ther. 2002;25:497-503. [PMID: 12381971]

67. Evans C, Gilbert JR, Taylor W, Hildebrand A. A randomized controlled trial of flexion exercises, education, and bed rest for patients with acute low back pain. Physiotherapy Canada. 1987;39:96-101.

68. Farrell JP, Twomey LT. Acute low back pain. Comparison of two conservative treatment approaches. Med J Aust. 1982;1:160-4. [PMID: 6210835] 69. Gilbert JR, Taylor DW, Hildebrand A, Evans C. Clinical trial of common treatments for low back pain in family practice. Br Med J (Clin Res Ed). 1985; 291:791-4. [PMID: 2931153]

70. Johannsen F, Remvig L, Kryger P, Beck P, Warming S, Lybeck K, et al. Exercises for chronic low back pain: a clinical trial. J Orthop Sports Phys Ther. 1995;22:52-9. [PMID: 7581431]

71. Kendall PH, Jenkins JM. Exercises for backache: a double-blind controlled trial. Physiother. 1968;54:154-7.

72. Kuukkanen TM, Mälkiä EA. An experimental controlled study on postural sway and therapeutic exercise in subjects with low back pain. Clin Rehabil. 2000; 14:192-202. [PMID: 10763797]

73. Lidström A, Zachrisson M. Physical therapy on low back pain and sciatica. An attempt at evaluation. Scand J Rehabil Med. 1970;2:37-42. [PMID: 4257208] 
74. Lie H, Frey S. [Mobilizing or stabilizing exercise in degenerative disk disease in the lumbar region?]. Tidsskr Nor Laegeforen. 1999;119:2051-3. [PMID: 10394282]

75. Risch SV, Norvell NK, Pollock ML, Risch ED, Langer H, Fulton M, et al. Lumbar strengthening in chronic low back pain patients. Physiologic and psychological benefits. Spine. 1993;18:232-8. [PMID: 8185727]

76. Seferlis T, Nemeth G, Carlsson AM, Gillstrom P. Conservative treatment in patients sick-listed for acute low-back pain: a prospective randomised study with 12 months' follow-up. Eur Spine J. 1998;7:461-70. [PMID: 9883955]

77. Seferlis T, Lindholm L, Németh G. Cost-minimisation analysis of three conservative treatment programmes in 180 patients sick-listed for acute low-back pain. Scand J Prim Health Care. 2000;18:53-7. [PMID: 10811045]

78. Tritilanunt $T$, Wajanavisit $W$. The efficacy of an aerobic exercise and health education program for treatment of chronic low back pain. J Med Assoc Thai. 2001;84 Suppl 2:S528-33. [PMID: 11853276]

79. Turner JA, Clancy S, McQuade KJ, Cardenas DD. Effectiveness of behavioral therapy for chronic low back pain: a component analysis. J Consult Clin Psychol. 1990;58:573-9. [PMID: 2147702]

80. Underwood MR, Morgan J. The use of a back class teaching extension exercises in the treatment of acute low back pain in primary care. Fam Pract. 1998;15:9-15. [PMID: 9527292]

81. Waterworth RF, Hunter IA. An open study of diflunisal, conservative and manipulative therapy in the management of acute mechanical low back pain. $\mathrm{NZ}$ Med J. 1985;98:372-5. [PMID: 3157894]

82. Zylbergold RS, Piper MC. Lumbar disc disease: comparative analysis of physical therapy treatments. Arch Phys Med Rehabil. 1981;62:176-9. [PMID: 6453571]

83. Calmels P, Jacob JF, Fayolle-Minon I, Charles C, Bouchet JP, Rimaud D, et al. [Use of isokinetic techniques vs standard physiotherapy in patients with chronic low back pain. Preliminary results]. Ann Readapt Med Phys. 2004;47: 20-7. [PMID: 14967569]

84. Frost H, Lamb SE, Doll HA, Carver PT, Stewart-Brown S. Randomised controlled trial of physiotherapy compared with advice for low back pain. BMJ. 2004:329:708. [PMID: 15377573]

85. Galantino ML, Bzdewka TM, Eissler-Russo JL, Holbrook ML, Mogck EP, Geigle P, et al. The impact of modified Hatha yoga on chronic low back pain: a pilot study. Altern Ther Health Med. 2004;10:56-9. [PMID: 15055095]

86. Gur A, Karakoc M, Cevik R, Nas K, Sarac AJ, Karakoc M. Efficacy of low power laser therapy and exercise on pain and functions in chronic low back pain. Lasers Surg Med. 2003;32:233-8. [PMID: 12605431]

87. Jousset N, Fanello S, Bontoux L, Dubus V, Billabert C, Vielle B, et al. Effects of functional restoration versus 3 hours per week physical therapy: a randomized controlled study. Spine. 2004;29:487-93; discussion 494. [PMID: 15129059]

88. Niemistö L, Lahtinen-Suopanki T, Rissanen P, Lindgren KA, Sarna S, Hurri $\mathrm{H}$. A randomized trial of combined manipulation, stabilizing exercises, and physician consultation compared to physician consultation alone for chronic low back pain. Spine. 2003;28:2185-91. [PMID: 14520029]

89. Rasmussen-Barr E, Nilsson-Wikmar L, Arvidsson I. Stabilizing training compared with manual treatment in sub-acute and chronic low-back pain. Man Ther. 2003;8:233-41. [PMID: 14559046]

90. Staal JB, Hlobil H, Twisk JW, Smid T, Köke AJ, van Mechelen W. Graded activity for low back pain in occupational health care: a randomized, controlled trial. Ann Intern Med. 2004;140:77-84. [PMID: 14734329]

91. Storheim K, Brox JI, Holm I, Koller AK, Bø K. Intensive group training versus cognitive intervention in sub-acute low back pain: short-term results of a single-blind randomized controlled trial. J Rehabil Med. 2003;35:132-40. [PMID: 12809196]

92. Yelland MJ, Glasziou PP, Bogduk N, Schluter PJ, McKernon M. Prolotherapy injections, saline injections, and exercises for chronic low-back pain: a randomized trial. Spine. 2004;29:9-16; discussion 16. [PMID: 14699269]

93. Yeung CK, Leung MC, Chow DH. The use of electro-acupuncture in conjunction with exercise for the treatment of chronic low-back pain. J Altern Complement Med. 2003;9:479-90. [PMID: 14499023]

94. Yozbatiran N, Yildirim Y, Parlak B. Effects of fitness and aquafitness exercises on physical fitness in patients with chronic low back pain. The Pain Clinic. 2004; 16:35-42.

95. Hides JA, Richardson CA, Jull GA. Multifidus muscle recovery is not automatic after resolution of acute, first-episode low back pain. Spine. 1996;21:2763-9. [PMID: 8979323]

96. Hayden JA, van Tulder MW, Tomlinson G. Systematic review: strategies for using exercise therapy to improve outcomes in chronic low back pain. Ann Intern Med. 2005;142:776-85.

97. Deyo RA, Battie M, Beurskens AJ, Bombardier C, Croft P, Koes B, et al. Outcome measures for low back pain research. A proposal for standardized use. Spine. 1998;23:2003-13. [PMID: 9779535]

98. Begg C, Cho M, Eastwood S, Horton R, Moher D, Olkin I, et al. Improving the quality of reporting of randomized controlled trials. The CONSORT statement. JAMA. 1996;276:637-9. [PMID: 8773637]

99. Waddell G, Feder G, Lewis M. Systematic reviews of bed rest and advice to stay active for acute low back pain. Br J Gen Pract. 1997;47:647-52. [PMID: 9474831]

100. Pengel HM, Maher CG, Refshauge KM. Systematic review of conservative interventions for subacute low back pain. Clin Rehabil. 2002;16:811-20. [PMID: 12501942] 
Current Author Addresses: Dr. Hayden: Institute for Work \& Health, 481 University Avenue, Suite 800, 8th Floor, Toronto, Ontario M5G 2E9, Canada.

Dr. van Tulder: Institute for Research in Extramural Medicine, VU University Medical Center, van der Boechorststraat 7, 1081 BT Amsterdam, the Netherlands.

Dr. Malmivaara: Finnish Office for Health Care Technology Assessment, PO Box 220, FIN-00531 Helsinki, Finland.

Dr. Koes: Department of General Practice, Erasmus University Medical Center, PO Box 1738, 3000 DR Rotterdam, the Netherlands. 
Appendix Table 1. Characteristics of Included Randomized, Controlled Trials*

\begin{tabular}{|c|c|c|c|c|}
\hline Study, Year (Reference) & Patients, $n$ & Study Methods $†$ & Source & $\begin{array}{l}\text { Duration of Low } \\
\text { Back Pain }\end{array}$ \\
\hline Chok et al., 1999 (62) & 54 & $+, ?,+,-$ & Secondary or tertiary care (referred) & Acute \\
\hline Delitto et al., 1993 (65) & 24 & $-, ?, ?,-$ & Secondary or tertiary care (referred) & Acute \\
\hline Faas et al., 1993 (37) & 473 &,,,+++- & Primary care & Acute \\
\hline Farrell and Twomey, 1982 (68) & 48 & $-, ?,+,+$ & Unclear & Acute \\
\hline Hides et al., 1996 (95) & 41 &,,,+++- & Secondary or tertiary care (referred) & Acute \\
\hline Malmivaara et al., 1995 (25) & 186 &,,,++++ & Occupational & Acute \\
\hline Seferlis et al., 1998 (76) & 180 & $-, ?,-,+$ & Occupational & Acute \\
\hline Stankovic and Johnell, 1990 (54) & 100 &,,,$+++ ?$ & Unclear & Acute \\
\hline Davies et al., 1979 (64) & 43 & $-, ?,+,+$ & Primary care & Subacute \\
\hline Lindström et al., 1992 (22) & 103 &,,,++++ & Occupational & Subacute§ \\
\hline Moffett et al., 1999 (47) & 187 &,,,+++- & Primary care & Subacute§ \\
\hline Staal et al., 2004 (90) & 134 &,,,+++- & Occupational & Subacute \\
\hline Storheim et al., 2003 (91) & 93 &,,,++-- & Occupational & Subacute \\
\hline \multicolumn{5}{|l|}{ Chronic populations } \\
\hline Alexandre et al., 2001 (56) & 33 & $?, ?,+, ?$ & Occupational & Chronic \\
\hline Aure et al., 2003 (32) & 49 &,,,+++- & Occupational & Chronic \\
\hline
\end{tabular}




\begin{tabular}{|c|c|c|c|c|}
\hline \multirow[t]{2}{*}{ Exercise Description } & \multicolumn{3}{|c|}{ Exercise Intervention Characteristics } & \multirow[t]{2}{*}{ Comparison Group } \\
\hline & $\begin{array}{l}\text { Intervention } \\
\text { Time, } h \neq\end{array}$ & Delivery Format & Other Interventions & \\
\hline $\begin{array}{l}\text { 1) Extensor endurance program: } \\
\text { aerobics, stretching, strengthening }\end{array}$ & 13.5 & Individual & $\begin{array}{l}\text { Advice to stay active or education; } \\
\text { passive modality }\end{array}$ & No treatment \\
\hline $\begin{array}{l}\text { 1) Williams flexion exercise regimen } \\
\text { with home exercises }\end{array}$ & 7.3 & Individual & Manual therapy & \\
\hline $\begin{array}{l}\text { 2) McKenzie regimen, plus long-lever } \\
\text { manipulation }\end{array}$ & 7.3 & Individual & Manual therapy & \\
\hline \multirow[t]{2}{*}{$\begin{array}{l}\text { 1) } 8 \text { exercises: "resting position," side } \\
\text { bending, stretching, isometric } \\
\text { abdominal strengthening }\end{array}$} & 3.3 & Individual & $\begin{array}{l}\text { Advice to stay active or education; } \\
\text { analgesics or NSAIDs }\end{array}$ & 1) Sham treatment \\
\hline & & & & 2) Usual general practitioner care \\
\hline $\begin{array}{l}\text { 1) Isometric abdominal exercises, } \\
\text { ergonomic advice, home abdominal } \\
\text { exercises }\end{array}$ & 2.7 & $\begin{array}{l}\text { Individual; independent } \\
\text { home exercises }\end{array}$ & $\begin{array}{l}\text { Advice to stay active or education; } \\
\text { passive modality }\end{array}$ & Other conservative treatment \\
\hline $\begin{array}{l}\text { 1) Adapted Kendall flexion routine } \\
\text { (home program), education, plus } \\
\text { analgesics }\end{array}$ & 4.8 & $\begin{array}{l}\text { Independent home } \\
\text { exercises }\end{array}$ & $\begin{array}{l}\text { Advice to stay active or education; } \\
\text { analgesics or NSAIDs }\end{array}$ & 1) Usual general practitioner care \\
\hline $\begin{array}{l}\text { 2) Exercise, education, plus bed rest } \\
\text { for } 4 d\end{array}$ & 4.8 & $\begin{array}{l}\text { Independent home } \\
\text { exercises }\end{array}$ & Education; bed rest & 2) Other conservative treatment \\
\hline 1) Multifidus isometric retraining & NA & NA & $\begin{array}{l}\text { Advice to stay active or education; } \\
\text { analgesics or NSAIDs }\end{array}$ & Usual general practitioner care \\
\hline $\begin{array}{l}\text { 1) Flexibility or mobilizing exercises: } \\
\text { back extension, lateral bending } \\
\text { movements }\end{array}$ & 10 & $\begin{array}{l}\text { Independent home } \\
\text { exercises }\end{array}$ & $\begin{array}{l}\text { Advice to stay active or education; } \\
\text { analgesics or NSAIDs }\end{array}$ & $\begin{array}{l}\text { 1) No treatment } \\
\text { 2) Other conservative treatment }\end{array}$ \\
\hline $\begin{array}{l}\text { 1) Intensive training program: } \\
\text { information, muscle training, and } \\
\text { general conditioning }\end{array}$ & 130.5 & Group & Advice to stay active or education & $\begin{array}{l}\text { 1) Other conservative } \\
\text { 2) Usual general practitioner care } \\
\text { treatment }\end{array}$ \\
\hline 1) McKenzie analysis and exercises & 2 & $\begin{array}{l}\text { Individual; independent } \\
\text { home exercises }\end{array}$ & Advice to stay active or education & No treatment \\
\hline $\begin{array}{l}\text { 1) Education on McKenzie principles, } \\
\text { teaching extension exercises, plus } \\
\text { general advice }\end{array}$ & 1.8 & Group & $\begin{array}{l}\text { Advice to stay active or education; } \\
\text { analgesics or NSAIDs }\end{array}$ & Usual general practitioner care \\
\hline $\begin{array}{l}\text { 1) Conservative physiotherapy } \\
\text { including active flexion and } \\
\text { extension exercises }\end{array}$ & 6.3 & Individual & Advice to stay active or education & $\begin{array}{l}\text { 1) Other conservative treatment } \\
\text { 2) Other conservative treatment }\end{array}$ \\
\hline
\end{tabular}

\begin{tabular}{|c|c|c|c|c|}
\hline $\begin{array}{l}\text { 1) McKenzie exercise program } \\
\text { (trained physiotherapists, centralize } \\
\text { symptoms) }\end{array}$ & 7.3 & Individual & Advice to stay active or education & 1) No treatment \\
\hline $\begin{array}{l}\text { 1) Extension exercises ("prone, raising } \\
\text { trunk" described as back-muscle } \\
\text { strengthening) }\end{array}$ & 9.6 & Individual & Passive modality & Other conservative treatment \\
\hline $\begin{array}{l}\text { 2) Flexion exercises (described as } \\
\text { "mobilizing") }\end{array}$ & 9.6 & Individual & Passive modality & \\
\hline $\begin{array}{l}\text { 1) Individual graded-activity program } \\
\text { (quota-based): endurance, } \\
\text { strengthening, aerobics }\end{array}$ & 133 & $\begin{array}{l}\text { Individual; independent } \\
\text { home exercises }\end{array}$ & $\begin{array}{l}\text { Advice to stay active or education; } \\
\text { back school }\end{array}$ & Usual general practitioner care \\
\hline 1) Aerobics, strengthening, stretching & 8 & Group & $\begin{array}{l}\text { Behavioral therapy; advice to stay } \\
\text { active or education }\end{array}$ & Usual general practitioner care \\
\hline 1) Graded-activity program & 13 & Individual & Advice to stay active or education & Usual general practitioner care \\
\hline $\begin{array}{l}\text { 1) Intensive training program: } \\
\text { aerobic, strength, flexibility }\end{array}$ & 31 & Group & None & $\begin{array}{l}\text { 1) Other conservative treatment } \\
\text { 2) Usual general practitioner care }\end{array}$ \\
\hline $\begin{array}{l}\text { 1) Several components: exercise, plus } \\
\text { home exercises }\end{array}$ & 24 & Group & Advice to stay active or education & No treatment \\
\hline $\begin{array}{l}\text { 1) Stretching exercises ( } 2 \text { of } 3 \text { ); } \\
\text { passive manipulation ( } 1 \text { of } 3 \text { ) }\end{array}$ & 10 & $\begin{array}{l}\text { Individual; independent } \\
\text { home exercises }\end{array}$ & $\begin{array}{l}\text { Manual therapy; analgesics or } \\
\text { NSAIDs }\end{array}$ & \\
\hline $\begin{array}{l}\text { 2) Individually designed: } \\
\text { strengthening, stretching, } \\
\text { mobilizing, coordination, and } \\
\text { stabilizing exercises for abdomen, } \\
\text { back, pelvis, and lower limb; } \\
\text { equipment }\end{array}$ & 10 & $\begin{array}{l}\text { Individual; independent } \\
\text { home exercises }\end{array}$ & Analgesics or NSAIDs & \\
\hline
\end{tabular}




\begin{tabular}{|c|c|c|c|c|}
\hline Study, Year (Reference) & Patients, $n$ & Study Methodst & Source & $\begin{array}{l}\text { Duration of Low } \\
\text { Back Pain }\end{array}$ \\
\hline Bendix et al., 1995 (57) & 106 & $+, ?,-,-$ & Secondary or tertiary care (referred) & Chronic \\
\hline Bentsen et al., 1997 (33) & 74 &,,,+++- & General population & Chronic§ \\
\hline Buswell, 1982 (61) & 50 & $-, ?,-,-$ & Primary care & Chronic§ \\
\hline Calmels et al., 2004 (83) & 17 & $?, ?,+,-$ & Secondary or tertiary care (referred) & Chronic \\
\hline Dalichau and Scheele, 2000 (63) & 63 & $?, ?,+,-$ & Secondary or tertiary care (referred) & Chronic \\
\hline Frost et al., 1995 (19) & 71 &,,,++++ & Primary care & Chronic \\
\hline Frost et al., 2004 (84) & 286 &,,,++-- & Secondary or tertiary care (referred) & Chronic§ \\
\hline Galantino et al., 2004 (85)\| & 22 & $+, ?,-,-$ & Mixed & Chronic \\
\hline Gur et al., 2003 (86) & 75 & $?, ?,+,-$ & Secondary or tertiary care (referred) & Chronic \\
\hline Hansen et al., 1993 (21) & 180 &,,,++++ & Mixed & Chronic§ \\
\hline Hemmilä et al., 1997 (40) & 114 &,,,-+++ & Mixed & Chronic \\
\hline Hildebrandt et al., 2000 (43) & 222 &,,,++-- & Primary care & Chronic \\
\hline
\end{tabular}




\begin{tabular}{|c|c|c|c|c|}
\hline \multirow[t]{2}{*}{ Exercise Description } & \multicolumn{3}{|c|}{ Exercise Intervention Characteristics } & \multirow[t]{2}{*}{ Comparison Group } \\
\hline & $\begin{array}{l}\text { Intervention } \\
\text { Time, } h \neq\end{array}$ & Delivery Format & Other Interventions & \\
\hline $\begin{array}{l}\text { 1) Aerobics and strengthening } \\
\text { (machines) }\end{array}$ & 36 & Group & None & \\
\hline $\begin{array}{l}\text { 2) Functional restoration; } \\
\text { comprehensive multidisciplinary } \\
\text { approach including aerobics, } \\
\text { strengthening, stretching }\end{array}$ & 36 & Group & Behavioral therapy; back school & \\
\hline $\begin{array}{l}\text { 1) Functional restoration; } \\
\text { comprehensive multidisciplinary } \\
\text { approach including aerobics, } \\
\text { strengthening, stretching }\end{array}$ & 24 & Group & Behavioral therapy; back school & Other conservative treatment \\
\hline 2) Aerobics and strengthening & 24 & Group & Back school & \\
\hline $\begin{array}{l}\text { 1) Dynamic strength back exercises: } \\
\text { at gym and home }\end{array}$ & 21.8 & $\begin{array}{l}\text { Individual; independent } \\
\text { home exercises }\end{array}$ & None & \\
\hline 2) Home exercises & 21.8 & $\begin{array}{l}\text { Independent home } \\
\text { exercises only }\end{array}$ & None & \\
\hline $\begin{array}{l}\text { 1) Dynamic trunk (Manniche) and } \\
\text { abdominal strengthening }\end{array}$ & 20 & Individual & Manual therapy & Other conservative treatment \\
\hline 2) Same exercise plus NSAIDs & 20 & Individual & Analgesics or NSAIDs & \\
\hline $\begin{array}{l}\text { 1) Extension exercise program (cites } \\
\text { McKenzie) }\end{array}$ & 11 & Individual & $\begin{array}{l}\text { Manual therapy; advice to stay } \\
\text { active or education }\end{array}$ & \\
\hline $\begin{array}{l}\text { 2) Flexion program (mobilizing } \\
\text { exercises plus posture) }\end{array}$ & 11 & Individual & $\begin{array}{l}\text { Manual therapy; advice to stay } \\
\text { active or education }\end{array}$ & \\
\hline $\begin{array}{l}\text { 1) Isokinetic strengthening exercises } \\
\text { (Cybex [Medway, Massachusetts] } \\
\text { machines) }\end{array}$ & 4.5 & Individual & Manual therapy & \\
\hline $\begin{array}{l}\text { 2) Physiotherapy exercises: series of } 3 \\
\text { groups of exercises (whole body) }\end{array}$ & 4.5 & Individual & None & \\
\hline $\begin{array}{l}\text { 1) Strengthening: warm-up aerobic } \\
\text { exercises, } 60 \text {-min equipment } \\
\text { training (total body) }\end{array}$ & 12 & Individual & Lumbar support & No treatment \\
\hline $\begin{array}{l}\text { 2) Same as above with no lumbar } \\
\text { support during exercises }\end{array}$ & 12 & Individual & None & \\
\hline $\begin{array}{l}\text { 1) Standard stretching or } \\
\text { strengthening program }\end{array}$ & 18.3 & $\begin{array}{l}\text { Independent home } \\
\text { exercises }\end{array}$ & None & \\
\hline $\begin{array}{l}\text { 2) Force, extensibility exercises of } \\
\text { trunk and hip muscles based on } \\
\text { initial evaluation; targeted increased }\end{array}$ & 18.3 & $\begin{array}{l}\text { Supervised home } \\
\text { exercises }\end{array}$ & None & \\
\hline $\begin{array}{l}\text { 1) } 12 \text { sequential relaxation and } \\
\text { stretching exercises (improve } \\
\text { flexibility); exercises plus TENS }\end{array}$ & 10.6 & $\begin{array}{l}\text { Supervised home } \\
\text { exercises }\end{array}$ & $\begin{array}{l}\text { Advice to stay active or education; } \\
\text { passive modality }\end{array}$ & Other conservative treatment \\
\hline $\begin{array}{l}\text { 1) Extension exercises ("prone, raising } \\
\text { trunk" described as back-muscle } \\
\text { strengthening) }\end{array}$ & 7 & $\begin{array}{l}\text { Supervised home } \\
\text { exercises }\end{array}$ & None & \\
\hline $\begin{array}{l}\text { 2) Flexion exercises (described as } \\
\text { "mobilizing") }\end{array}$ & 7 & $\begin{array}{l}\text { Supervised home } \\
\text { exercises }\end{array}$ & None & \\
\hline $\begin{array}{l}\text { 1) Warm-up, stretching, progressive } \\
\text { exercises, light aerobic and advice, } \\
\text { plus back school }\end{array}$ & 8 & Group & $\begin{array}{l}\text { Advice to stay active or education; } \\
\text { back school }\end{array}$ & Other conservative treatment \\
\hline $\begin{array}{l}\text { 1) Standard physiotherapy: } 94 \% \\
\text { received exercises (stretching, } \\
\text { strengthening, mobility exercises) }\end{array}$ & 3.5 & Individual & $\begin{array}{l}\text { Manual therapy; advice to stay } \\
\text { active or education }\end{array}$ & Other conservative treatment \\
\hline $\begin{array}{l}\text { 1) Hatha yoga: sequence of postures } \\
\text { that leads to a state of relaxation } \\
\text { (strength, flexibility, balance) }\end{array}$ & 19.5 & $\begin{array}{l}\text { Group; independent } \\
\text { home exercises }\end{array}$ & None & No treatment \\
\hline $\begin{array}{l}\text { 1) Stretching and strengthening } \\
\text { exercises of lumbar and extremity } \\
\text { muscle groups }\end{array}$ & 5 & $\begin{array}{l}\text { Independent home } \\
\text { exercises }\end{array}$ & None & Other conservative treatment \\
\hline $\begin{array}{l}\text { 2) Same exercises as above with } \\
\text { additional intervention }\end{array}$ & 5 & $\begin{array}{l}\text { Independent home } \\
\text { exercises }\end{array}$ & Low-power laser therapy & \\
\hline $\begin{array}{l}\text { 1) Intensive dynamic back-muscle } \\
\text { training: extension strengthening }\end{array}$ & 8 & Individual & None & $\begin{array}{l}\text { 1) Other conservative treatment } \\
\text { 2) Other conservative treatment }\end{array}$ \\
\hline $\begin{array}{l}\text { 1) Bending, rotation exercises; } \\
\text { "auto-stretching when } \\
\text { appropriate" }\end{array}$ & 13.8 & $\begin{array}{l}\text { Independent home } \\
\text { exercises }\end{array}$ & None & $\begin{array}{l}\text { 1) Other conservative treatment } \\
\text { 2) Other conservative treatment }\end{array}$ \\
\hline 1) Postural exercises (Cesar therapy) & 10.5 & Individual & None & Usual general practitioner care \\
\hline
\end{tabular}




\begin{tabular}{|c|c|c|c|c|}
\hline \multirow[t]{2}{*}{ Study, Year (Reference) } & \multirow[t]{2}{*}{ Patients, $n$} & \multirow[t]{2}{*}{ Study Methodst } & \multicolumn{2}{|c|}{ Population Characteristics } \\
\hline & & & Source & $\begin{array}{l}\text { Duration of Low } \\
\text { Back Pain }\end{array}$ \\
\hline Johannsen et al., 1995 (70) & 27 & $-, ?,-,-$ & Secondary or tertiary care (referred) & Chronic \\
\hline Jousset et al., 2004 (87) & 85 & $+, ?,+,-$ & Occupational & Chronic \\
\hline Kankaanpää et al., 1999 (44) & 54 &,,,+++- & Occupational & Chronic \\
\hline Kendall and Jenkins, 1968 (71) & 42 & $-, ?,+,-$ & Primary care & Chronic \\
\hline Kuukkanen and Mälkiä, 2000 (72) & 57 & $?, ?,+,-$ & Occupational & Chronic§ \\
\hline Lidström and Zachrisson, 1970 (73) & 62 & $-, ?,+, ?$ & Secondary or tertiary care (referred) & Chronic§ \\
\hline Lie and Frey, 1999 (74) & 27 & $+, ?,-,+$ & Primary care & Chronic \\
\hline Manniche et al., 1988 (26) & 105 &,,,++++ & Secondary or tertiary care (referred) & Chronic \\
\hline Mannion et al., 1999 (29) & 148 &,,,++++ & General population & Chronic \\
\hline Moseley, 2002 (48) & 57 &,,,++-- & Primary care & Chronic \\
\hline Niemistö et al., 2003 (88) & 204 &,,,+++- & General population & Chronic \\
\hline Petersen et al., 2002 (49) & 260 &,,,++-+ & Secondary or tertiary care (referred) & Chronic \\
\hline Preyde, 2000 (50) & 98 &,,,+-++ & Mixed & Chronic§ \\
\hline Rasmussen-Barr et al., 2003 (89) & 47 & $?, ?,-,-$ & Primary care & Chronic§ \\
\hline Risch et al., 1993 (75) & 54 &,,,--+- & Secondary or tertiary care (referred) & Chronic \\
\hline
\end{tabular}




\section{Exercise Description}

1) Aerobics, exercises emphasizing coordination, balance, stability, stretching

2) Aerobics, dynamic exercises emphasizing muscle endurance: abdominal, shoulder, hip muscle stretching

1) Functional restoration

2) Active individual therapy (strengthening, stretching, aerobics recommended)

1) Strengthening (machines) with stretching, coordination (David Beck Clinic program)

1) Mobilizing, strengthening, posture

2) Isometric flexion exercises: strengthening abdominal and trunk muscles (2 exercises)

3) Strengthening extension muscles, posture, lifting

1) Strengthening, endurance, balance and coordination

1) Mobilizing (kneeling and supine) and strengthening (isotonic abdominal and back) exercises and home exercises

1) Mobilizing and stretching, walking in "flexible way"

2) Stabilizing exercises and walking without instructions

1) Intensive strengthening: trunk, back strengthening routine

2) Back strengthening routine; similar to group 1, lower dose

3) Isometric exercises for lower back

1) Aerobics, stretching

2) Controlled progressive exercises with machines (David Beck Clinic program)

3) Physiotherapy including exercises using resistance bands and general strength training

1) Specific trunk muscle training: individualized with home exercise program (Richardson and Jull)

1) Stabilizing exercises aiming to correct lumbopelvic rhythm

1) Strengthening training: stationary bike, intensive dynamic back strengthening in flexion and extension

2) McKenzie therapy

1) Stretching, flexion or extension, "general strengthening or mobility"

2) Comprehensive massage (massage and exercises)

1) Stabilizing exercises: activation and control deep abdominal, multifidus muscles

1) Dynamic extension strengthening program (machine)

21

4
Exercise Intervention Characteristics

Comparison Group

Other Interventions

None

24 Group None

$\begin{array}{rll}150 & \begin{array}{l}\text { Group } \\ \text { Individual; independent } \\ \text { home exercises }\end{array} & \begin{array}{l}\text { None } \\ \text { Advice to stay active or education }\end{array} \\ 36 & \text { Group } & \begin{array}{c}\text { Behavioral therapy; advice to stay } \\ \text { active or education }\end{array}\end{array}$

7.9 Independent home Advice to stay active or education

7.9 Independent home Advice to stay active or education

exercises

7.9 Independent home Advice to stay active or education

exercises

Independent home

exercises only

4.8

Individual; independent

home exercises

None

No treatment

Passive modality

1) Other conservative treatment

2) Other conservative treatment

15

Group; independent None

home exercises

Group; independent None

home exercises

45 Individual None

$45 \quad$ Individual None

$45 \quad$ Individual Manual therapy; passive modality

24 Group None

24 Group None

17.6 Individual Ergonomic advice; passive modality

12 Individual; independent

home exercises

Manual therapy; advice to stay

Usual general practitioner care active or education

Individual; independent

Manual therapy; advice to stay

Usual general practitioner care

home exercises

active or education

6.9 Group None

None

6.9 Individual None

2 Individual Manual therapy 1 ) Sham treatment

$2 \quad$ Individual

Advice to stay active or education

2) Other conservative treatment

Individual; supervised

Advice to stay active or education

Other conservative treatment

home exercises

11.4

Individual

None

No treatment 


\begin{tabular}{|c|c|c|c|c|}
\hline Study, Year (Reference) & Patients, $n$ & Study Methodst & Source & $\begin{array}{l}\text { Duration of Low } \\
\text { Back Pain }\end{array}$ \\
\hline Torstensen et al., 1998 (31) & 208 &,,,++++ & Occupational & Chronic \\
\hline Tritilanunt and Wajanavisit, 2001 (78) & 72 & $+, ?,+,-$ & Secondary or tertiary care (referred) & Chronic \\
\hline Turner et al., 1990 (79) & 96 &,,,++-- & Mixed & Chronic \\
\hline Yozbatiran et al., 2004 (94) & 30 & $?, ?,+,-$ & Secondary or tertiary care (referred) & Chronic \\
\hline Zylbergold and Piper, 1981 (82) & 28 & $-, ?,+,-$ & Primary care & Chronic§ \\
\hline \multicolumn{5}{|l|}{ Unclear population } \\
\hline Ljunggren et al., 1997 (45) & 126 &,,,+++- & Primary care & Unclear \\
\hline
\end{tabular}

* 61 studies were included: 11,6 , and 43 in acute, subacute, and chronic low back pain populations, respectively $(1$ unclear $) .+=$ yes; $-=$ no; ? = unknown; NA = not applicable; NSAIDs = nonsteroidal anti-inflammatory drugs; TENS = transcutaneous electrical nerve stimulation.

† Study method factors: adequate randomization, allocation concealment, adequate follow-up, outcome assessor blinding.

‡ Intervention time calculated as "best estimate" when a home exercise program was used and study adherence information was not available (see text).

$\S$ Sensitivity analysis as "mixed" population.

$\|$ Galantino et al. (85) was excluded from quantitative syntheses because of flaw: small study with $>50 \%$ loss to follow-up. 


\section{Appendix Table 1-Continued}

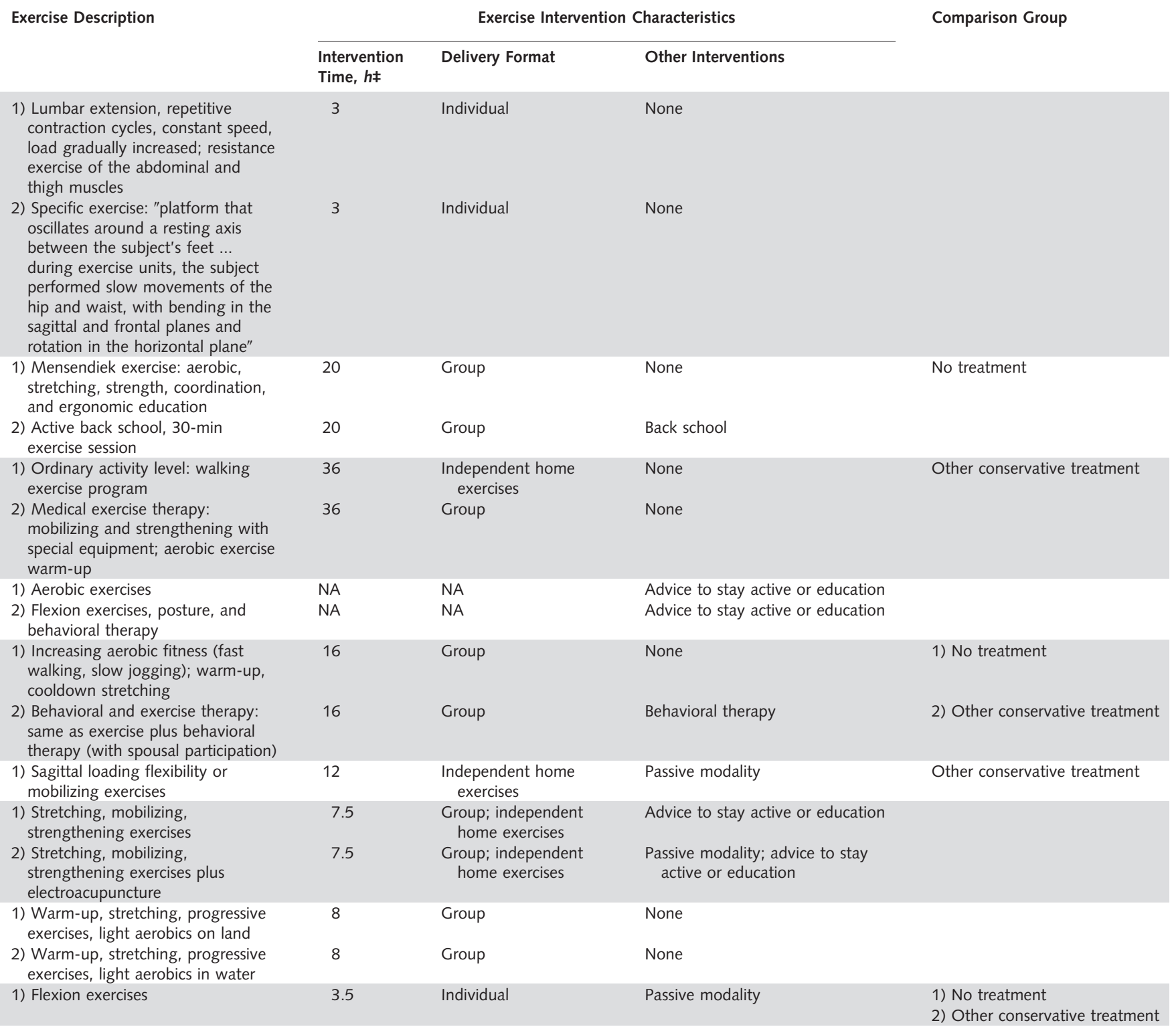

\begin{tabular}{|c|c|c|c|}
\hline $\begin{array}{l}\text { 1) Terapi Master (Nordisk Terapi, } \\
\text { Arendal, Norway) device for } \\
\text { general exercise: strengthening, } \\
\text { stretching }\end{array}$ & 39 & $\begin{array}{l}\text { Supervised home } \\
\text { exercises }\end{array}$ & None \\
\hline $\begin{array}{l}\text { 2) Conventional physical therapy } \\
\text { exercises: low-tech strengthening, } \\
\text { stretching }\end{array}$ & 39 & $\begin{array}{l}\text { Supervised home } \\
\text { exercises }\end{array}$ & None \\
\hline
\end{tabular}


Appendix Table 2. Results Available for Trials Included in Systematic Review*

\begin{tabular}{|c|c|c|c|c|c|c|c|c|c|c|}
\hline \multirow[t]{3}{*}{ Study, Year (Reference) } & \multirow{3}{*}{$\begin{array}{l}\text { Rating } \\
\text { of } \\
\text { Resultst }\end{array}$} & \multirow{3}{*}{$\begin{array}{l}\text { Outcome } \\
\text { Measures } \\
\text { Reported (Scale) }\end{array}$} & \multicolumn{2}{|c|}{ Initial Pain Intensity } & \multicolumn{6}{|c|}{ Pain Intensity at Follow-up } \\
\hline & & & \multirow[b]{2}{*}{ Ex } & \multirow[b]{2}{*}{ C } & \multicolumn{2}{|c|}{ Short-Term } & \multicolumn{2}{|c|}{ Intermediate } & \multicolumn{2}{|c|}{ Long-Term } \\
\hline & & & & & Ex & $\mathrm{C}$ & Ex & $\mathrm{C}$ & Ex & $\mathrm{C}$ \\
\hline \multicolumn{11}{|l|}{ Acute populations } \\
\hline Chok et al., 1999 (62)‡ & Positive & $\begin{array}{l}\text { Pain (VAS), function } \\
\text { (RMDQ) }\end{array}$ & $23.0 \pm 24.0$ & $26.7 \pm 19.7$ & $10.2 \pm 29.9$ & $22.8 \pm 18.5$ & $8.1 \pm 34.7$ & $20.1 \pm 24.4$ & & \\
\hline Delitto et al., 1993 (65) & $\begin{array}{l}\text { Unclear } \\
\text { Unclear }\end{array}$ & Function (ODQ) & & & & & & & & \\
\hline \multirow[t]{2}{*}{ Faas et al., 1993 (37) } & Neutral & $\begin{array}{l}\text { Pain (VAS/85 } \\
\text { points), function } \\
\text { (LOM), RTW }\end{array}$ & 36.1 & 36.6 & $17.1 \pm 21.0$ & $14.6 \pm 22.0$ & $12.1 \pm 24.0$ & $12.6 \pm 30.0$ & $10.1 \pm 23.0$ & $9.6 \pm 26.0$ \\
\hline & & & & 36.8 & & $17.8 \pm 23.0$ & & $14.8 \pm 28.0$ & & $10.8 \pm 26.0$ \\
\hline $\begin{array}{l}\text { Farrell and Twomey, } 1982 \\
\text { (68) }\end{array}$ & Neutral & $\begin{array}{l}\text { Pain (VAS/10 } \\
\text { points), function } \\
\text { (BU), global }\end{array}$ & 5.2 & 4.9 & 0.3 & 0.3 & & & & \\
\hline \multirow[t]{2}{*}{ Gilbert et al., 1985 (69)§ } & Neutral & $\begin{array}{l}\text { Pain (MPQ), } \\
\text { function (ADS) }\end{array}$ & $22.7 \pm 6.7$ & $25.2 \pm 8.6$ & $7.5 \pm 1.2$ & $7.7 \pm 2.0$ & & & & \\
\hline & Neutral & & $23.0 \pm 7.4$ & $25.1 \pm 6.9$ & $8.4 \pm 0.9$ & $8.6 \pm 1.3$ & & & & \\
\hline Hides et al., 1996 (95) & Neutral & $\begin{array}{l}\text { Pain (VAS), function } \\
\text { (RMDQ) }\end{array}$ & 42 & 47 & 0 & 11 & & & & \\
\hline \multirow[t]{2}{*}{$\begin{array}{l}\text { Malmivaara et al., } 1995 \\
\text { (25) }\end{array}$} & Negative & $\begin{array}{l}\text { Pain (VAS/10 } \\
\text { points), function } \\
\text { (ODQ), RTW }\end{array}$ & 6.1 & 5.9 & 3.1 & 2.4 & $1.8 \pm 1.8$ & $2.1 \pm 1.8$ & & \\
\hline & & & & 5.7 & & 1.9 & & 1.3 & & \\
\hline \multirow[t]{2}{*}{ Seferlis et al., 1998 (76) } & Neutral & $\begin{array}{l}\text { Pain (VAS/10 } \\
\text { points), function } \\
\text { (ODQ), RTW }\end{array}$ & $5.1 \pm 1.4$ & $5.1 \pm 1.4$ & $4.6 \pm 1.7$ & $4.6 \pm 1.7$ & $3.5 \pm 2.6$ & $3.5 \pm 2.6$ & $2.5 \pm 1.7$ & $2.5 \pm 1.7$ \\
\hline & & & & $5.1 \pm 1.4$ & & $4.6 \pm 1.7$ & & $3.5 \pm 2.6$ & & $2.5 \pm 1.7$ \\
\hline $\begin{array}{l}\text { Stankovic and Johnell, } \\
1990 \text { (54) }\end{array}$ & Unclear & Pain (VAS), RTW & & & & & & & & \\
\hline $\begin{array}{l}\text { Underwood and Morgan, } \\
1998(80)\end{array}$ & Neutral & $\begin{array}{l}\text { Pain (VAS), function } \\
\text { (ODQ), RTW, } \\
\text { global }\end{array}$ & 44.4 & 50.4 & $18.0 \pm 28.4$ & $23.4 \pm 28.4$ & $11.1 \pm 27.6$ & $12.0 \pm 27.6$ & $8.6 \pm 31.8$ & $13.7 \pm 31.8$ \\
\hline \multirow[t]{2}{*}{$\begin{array}{l}\text { Waterworth and Hunter, } \\
1985 \text { (81) }\end{array}$} & Unclear & $\begin{array}{l}\text { Pain (Likert/4 } \\
\text { points), global }\end{array}$ & 2.1 & 2.0 & 0.4 & 0.4 & & & & \\
\hline & & & & 2.1 & & 0.4 & & & & \\
\hline \multicolumn{11}{|l|}{ Subacute populations } \\
\hline \multirow[t]{2}{*}{ Cherkin et al., 1998 (35) } & Neutral & $\begin{array}{l}\text { Pain (VAS/10 } \\
\text { points), function } \\
\text { (RMDQ/23 } \\
\text { points), RTW }\end{array}$ & $6.0 \pm 2.5$ & $5.5 \pm 2.1$ & $2.3 \pm 2.9$ & $1.9 \pm 3.3$ & $2.7 \pm 2.8$ & $2.0 \pm 2.2$ & 2.0 & 1.6 \\
\hline & & & & $5.3 \pm 1.8$ & & $3.1 \pm 3.2$ & & $3.2 \pm 3.2$ & & 2.8 \\
\hline \multirow[t]{2}{*}{ Davies et al., 1979 (64) } & Unclear & $\begin{array}{l}\text { Pain (VAS), RTW, } \\
\text { global }\end{array}$ & $11.2 \pm 4.4$ & $8.7 \pm 3.3$ & $5.0 \pm 6.0$ & $6.0 \pm 5.1$ & $1.8 \pm 3.6$ & $3.7 \pm 5.4$ & & \\
\hline & Unclear & & $7.3 \pm 3.2$ & & $5.8 \pm 5.2$ & & $1.3 \pm 2.2$ & & & \\
\hline Lindström et al., 1992 (22) & Positive & Pain (VAS), RTW & $41.3 \pm 28.2$ & $44.5 \pm 28.8$ & & & & & & \\
\hline Moffett et al., 1999 (47) & Positive & $\begin{array}{l}\text { Pain (APS), function } \\
\text { (RMDQ), RTW }\end{array}$ & $27.9 \pm 11.1$ & $25.5 \pm 10.9$ & $16.4 \pm 9.9$ & $16.5 \pm 9.9$ & $17.7 \pm 12.0$ & $17.4 \pm 12.0$ & $15.0 \pm 11.2$ & $17.0 \pm 11.2$ \\
\hline Staal et al., 2004 (90) & Positive & $\begin{array}{l}\text { Pain (NRS/10 } \\
\text { points), function } \\
\text { (RMDQ), RTW }\end{array}$ & $6.7 \pm 1.8$ & $6.4 \pm 1.7$ & $2.8 \pm 2.4$ & $2.5 \pm 2.8$ & $2.9 \pm 3.1$ & $2.7 \pm 2.8$ & & \\
\hline Storheim et al., 2003 (91) & Neutral & $\begin{array}{l}\text { Pain (VAS), function } \\
\text { (RMDQ), RTW }\end{array}$ & $53.2 \pm 23.2$ & $55.7 \pm 19.6$ & & & $38.3 \pm 22.4$ & $34.8 \pm 25.1$ & & \\
\hline \multicolumn{11}{|l|}{ Chronic populations } \\
\hline Alexandre et al., 2001 (56) & Neutral & Pain (VAS/10 points) & $5.7 \pm 8.3$ & $5.8 \pm 14.7$ & $0.6 \pm 8.6$ & $3.7 \pm 11.3$ & & & & \\
\hline \multirow[t]{2}{*}{ Aure et al., 2003 (32) } & Positive & $\begin{array}{l}\text { Pain (VAS), function } \\
\text { (ODQ), RTW }\end{array}$ & $55.0 \pm 18.6$ & & $22.0 \pm 18.6$ & & $22.0 \pm 21.2$ & & $21.0 \pm 18.6$ & \\
\hline & Neutral & & $54.0 \pm 23.9$ & & $37.0 \pm 26.3$ & & $42.0 \pm 23.9$ & & $35.0 \pm 23.9$ & \\
\hline \multirow[t]{2}{*}{ Bendix et al., $2000(60) \neq$} & Neutral & $\begin{array}{l}\text { Pain (NRS), function } \\
\text { (MRS), RTW, } \\
\text { global }\end{array}$ & $6.0 \pm 1.5$ & & & & & & $5.7 \pm 3.9$ & \\
\hline & Neutral & & $5.1 \pm 2.7$ & & & & & & $5.1 \pm 4.5$ & \\
\hline \multirow[t]{2}{*}{ Bendix et al., 1995 (57)‡ } & Positive & $\begin{array}{l}\text { Pain (VAS/10 } \\
\text { points), function } \\
\text { (ADL/30 points), } \\
\text { RTW }\end{array}$ & 5.3 & & & & $2.7 \pm 2.3$ & & $3.3 \pm 3.4$ & \\
\hline & Negative & & 5.4 & 5.9 & & & $4.4 \pm 2.9$ & $5.6 \pm 2.9$ & $5.3 \pm 3.3$ & $6.5 \pm 2.5$ \\
\hline
\end{tabular}




\section{Appendix Table 2-Continued}

\begin{tabular}{|c|c|c|c|c|c|c|c|}
\hline \multicolumn{2}{|c|}{ Initial Functional Impairment } & \multicolumn{6}{|c|}{ Functional Impairment at Follow-up } \\
\hline \multirow[b]{2}{*}{ Ex } & \multirow[b]{2}{*}{ C } & \multicolumn{2}{|c|}{ Short-Term } & \multicolumn{2}{|c|}{ Intermediate } & \multicolumn{2}{|c|}{ Long-Term } \\
\hline & & Ex & $\mathrm{C}$ & Ex & $\mathrm{C}$ & Ex & $\mathrm{C}$ \\
\hline $11.5 \pm 4.0$ & $11.0 \pm 4.7$ & $4.0 \pm 6.4$ & $9.5 \pm 4.0$ & $3.0 \pm 5.8$ & $4.0 \pm 5.4$ & & \\
\hline $\begin{array}{l}41.0 \pm 3.5 \\
34.0 \pm 4.0\end{array}$ & & $\begin{array}{l}32.0 \pm 4.0 \\
10.0 \pm 4.0\end{array}$ & & & & & \\
\hline \multirow[t]{2}{*}{24.3} & 24.1 & $15.3 \pm 19.0$ & $13.1 \pm 17.0$ & $12.3 \pm 20.0$ & $12.1 \pm 18.0$ & $10.3 \pm 19.0$ & $10.1 \pm 18.0$ \\
\hline & 23.3 & & $13.3 \pm 18.0$ & & $10.3 \pm 19.0$ & & $8.3 \pm 19.0$ \\
\hline 1.8 & 1.9 & 1.2 & 1.1 & & & & \\
\hline $35.9 \pm 13.7$ & $36.3 \pm 13.1$ & $21.3 \pm 9.2$ & $24.3 \pm 10.0$ & & & & \\
\hline $40.4 \pm 16.4$ & $36.6 \pm 12.4$ & $24.4 \pm 8.8$ & $20.9 \pm 8.5$ & & & & \\
\hline 10.3 & 13.6 & 0 & 3 & & & & \\
\hline \multirow[t]{2}{*}{33.8} & 34.6 & $18.6 \pm 16.4$ & $16.0 \pm 16.4$ & $10.8 \pm 10.2$ & $11.8 \pm 10.2$ & & \\
\hline & $32.0 \pm 0.0$ & & $10.0 \pm 0.0$ & & $7.4 \pm 0.0$ & & \\
\hline $30.0 \pm 18.0$ & $30.0 \pm 18.0$ & $20.0 \pm 18.0$ & $20.0 \pm 18.0$ & $11.7 \pm 12.0$ & $11.7 \pm 12.0$ & $9.8 \pm 11.0$ & $9.8 \pm 11.0$ \\
\hline $30.0 \pm 18.0$ & & $20.0 \pm 18.0$ & & $11.7 \pm 12.0$ & & $9.8 \pm 11.0$ & \\
\hline 26.2 & 35.6 & $7.6 \pm 19.6$ & $11.5 \pm 19.6$ & $4.7 \pm 20.4$ & $7.0 \pm 20.4$ & $4.7 \pm 20.4$ & $8.0 \pm 20.4$ \\
\hline
\end{tabular}

\begin{tabular}{|c|c|c|c|c|c|c|c|}
\hline $12.2 \pm 5.6$ & $12.1 \pm 5.5$ & $4.1 \pm 4.6$ & $3.7 \pm 4.4$ & $4.1 \pm 5.0$ & $3.1 \pm 4.4$ & 2.6 & 2.6 \\
\hline & $11.7 \pm 5.4$ & & $4.9 \pm 4.3$ & & $4.3 \pm 4.9$ & & 4.5 \\
\hline $6.7 \pm 4.0$ & $5.6 \pm 3.9$ & $3.8 \pm 3.2$ & $3.6 \pm 3.2$ & $3.7 \pm 3.9$ & $3.9 \pm 3.9$ & $3.5 \pm 3.7$ & $3.8 \pm 3.7$ \\
\hline $13.3 \pm 4.6$ & $13.0 \pm 4.9$ & $6.3 \pm 6.7$ & $4.9 \pm 6.2$ & $7.8 \pm 6.6$ & $6.4 \pm 6.6$ & & \\
\hline $8.2 \pm 3.5$ & $8.9 \pm 3.4$ & & & $6.1 \pm 3.8$ & $5.5 \pm 4.1$ & & \\
\hline
\end{tabular}

\begin{tabular}{|c|c|c|c|c|c|c|}
\hline $39.0 \pm 13.2$ & & $18.0 \pm 13.2$ & $16.0 \pm 13.2$ & & $17.0 \pm 13.2$ & \\
\hline $39.0 \pm 14.3$ & & $30.0 \pm 12.0$ & $30.0 \pm 14.3$ & & $26.0 \pm 14.3$ & \\
\hline $16.0 \pm 7.4$ & & & & & $13.0 \pm 8.8$ & \\
\hline $16.0 \pm 5.9$ & & & & & $12.0 \pm 13.2$ & \\
\hline 15.5 & & & $8.5 \pm 9.5$ & & $8.9 \pm 6.0$ & \\
\hline 14.4 & 15.3 & & $13.5 \pm 5.1$ & $16.1 \pm 7.5$ & $13.7 \pm 6.9$ & $16.4 \pm 3.8$ \\
\hline
\end{tabular}




\section{Appendix Table 2-Continued}

\begin{tabular}{|c|c|c|c|c|c|c|c|c|c|c|}
\hline \multirow[t]{3}{*}{ Study, Year (Reference) } & \multirow{3}{*}{$\begin{array}{l}\text { Rating } \\
\text { of } \\
\text { Resultst }\end{array}$} & \multirow{3}{*}{$\begin{array}{l}\text { Outcome } \\
\text { Measures } \\
\text { Reported (Scale) }\end{array}$} & \multirow{2}{*}{\multicolumn{2}{|c|}{ Initial Pain Intensity }} & \multicolumn{6}{|c|}{ Pain Intensity at Follow-up } \\
\hline & & & & & \multicolumn{2}{|c|}{ Short-Term } & \multicolumn{2}{|c|}{ Intermediate } & \multicolumn{2}{|c|}{ Long-Term } \\
\hline & & & Ex & C & Ex & C & Ex & C & Ex & C \\
\hline \multirow[t]{2}{*}{ Bentsen et al., 1997 (33) } & Unclear & $\begin{array}{l}\text { Function (Million), } \\
\text { RTW }\end{array}$ & & & & & & & & \\
\hline & Neutral & & & & & & & & & \\
\hline \multirow[t]{2}{*}{ Bronfort et al., 1996 (34) } & Neutral & $\begin{array}{l}\text { Pain (VAS/10 } \\
\text { points), function } \\
\text { (RMDQ) }\end{array}$ & $5.3 \pm 1.5$ & $5.4 \pm 1.4$ & $3.4 \pm 1.9$ & $3.9 \pm 2.1$ & $2.7 \pm 2.0$ & $3.3 \pm 2.3$ & 2.9 & 2.9 \\
\hline & Neutral & & $5.5 \pm 1.7$ & & $3.6 \pm 2.2$ & & $3.5 \pm 2.2$ & & 3.2 & \\
\hline \multirow[t]{2}{*}{ Buswell, 1982 (61) } & Unclear & $\begin{array}{l}\text { Pain (unknown } \\
\text { measure) }\end{array}$ & $6.0 \pm 0.0$ & & $2.8 \pm 0.0$ & & & & & \\
\hline & Unclear & & $5.5 \pm 0.0$ & & $2.5 \pm 0.0$ & & & & & \\
\hline \multirow[t]{2}{*}{ Calmels et al., 2004 (83) } & Neutral & $\begin{array}{l}\text { Pain (VAS), function } \\
\text { (QDI) }\end{array}$ & & & & & & & & \\
\hline & Neutral & & & & & & & & & \\
\hline \multirow[t]{2}{*}{$\begin{array}{l}\text { Dalichau and Scheele, } \\
2000 \text { (63) }\end{array}$} & Unclear & $\begin{array}{l}\text { Pain (VAS/10 } \\
\text { points), function } \\
\text { (ODQ) }\end{array}$ & 6.3 & 5.5 & 2.1 & 5.5 & 3.3 & 5.6 & & \\
\hline & Unclear & & 5.8 & & 3.1 & & 5.2 & & & \\
\hline \multirow[t]{2}{*}{$\begin{array}{l}\text { Descarreaux et al., } 2002 \\
(66)\end{array}$} & Negative & $\begin{array}{l}\text { Pain (VAS), function } \\
\text { (ODQ) }\end{array}$ & 31.3 & & $27.8 \pm 9.0$ & & & & & \\
\hline & Positive & & 30.9 & & $16.6 \pm 9.7$ & & & & & \\
\hline Deyo et al., 1990 (18) & Positive & $\begin{array}{l}\text { Pain (VAS), function } \\
\text { (SIP), global }\end{array}$ & 43.6 & 38.9 & $19.8 \pm 20.4$ & $25.9 \pm 20.4$ & $26.5 \pm 24.6$ & $25.6 \pm 24.6$ & & \\
\hline \multirow[t]{2}{*}{ Elnaggar et al., 1991 (36) } & Positive & Pain (MPQ) & $15.9 \pm 7.8$ & & $10.6 \pm 8.6$ & & & & & \\
\hline & Positive & & $14.1 \pm 9.8$ & & $8.9 \pm 9.4$ & & & & & \\
\hline Frost et al., 1995 (19) & Positive & $\begin{array}{l}\text { Pain (VAS), function } \\
\text { (ODQ) }\end{array}$ & $20.9 \pm 12.3$ & $25.6 \pm 17.9$ & $12.1 \pm 9.9$ & $22.1 \pm 20.1$ & & & & \\
\hline Frost et al., 2004 (84) & Neutral & $\begin{array}{l}\text { Function (ODQ), } \\
\text { global }\end{array}$ & & & & & & & & \\
\hline $\begin{array}{l}\text { Galantino et al., } 2004 \\
\text { (85)\| }\end{array}$ & Unclear & Function (ODQ) & & & & & & & & \\
\hline \multirow[t]{2}{*}{ Gur et al., 2003 (86) } & Neutral & $\begin{array}{l}\text { Pain (VAS/10 } \\
\text { points), function } \\
\text { (RMDQ) }\end{array}$ & $6.2 \pm 2.1$ & $6.1 \pm 1.9$ & $1.8 \pm 1.2$ & $1.9 \pm 1.4$ & & & & \\
\hline & Neutral & & $6.5 \pm 1.6$ & & $2.9 \pm 1.3$ & & & & & \\
\hline \multirow[t]{2}{*}{ Hansen et al., 1993 (21)‡ } & Neutral & $\begin{array}{l}\text { Pain (VAS/9 points), } \\
\text { global }\end{array}$ & $3.5 \pm 0.9$ & $4.0 \pm 0.8$ & $3.0 \pm 0.7$ & $3.0 \pm 0.4$ & $4.0 \pm 1.2$ & $4.0 \pm 0.8$ & $2.5 \pm 0.8$ & $3.0 \pm 0.8$ \\
\hline & & & & $5.0 \pm 0.8$ & & $3.0 \pm 0.8$ & & $4.0 \pm 0.8$ & & $4.0 \pm 1.0$ \\
\hline \multirow[t]{2}{*}{ Hemmilä et al., 1997 (40) } & Positive & Pain (VAS) & 40.0 & 46.0 & 30.0 & 30.0 & 29.0 & 25.0 & & \\
\hline & & & & 43.0 & & 25.0 & & 25.0 & & \\
\hline $\begin{array}{l}\text { Hildebrandt et al., } 2000 \\
\text { (43) }\end{array}$ & Positive & Global & & & & & & & & \\
\hline \multirow[t]{2}{*}{$\begin{array}{l}\text { Johanssen et al., } 1995 \\
(70) \ddagger\end{array}$} & Unclear & $\begin{array}{l}\text { Pain (Likert/9 } \\
\text { points), function } \\
\text { (ADL/12 points), } \\
\text { RTW }\end{array}$ & $6.0 \pm 1.7$ & & $5.0 \pm 2.6$ & & $4.0 \pm 2.6$ & & & \\
\hline & Unclear & & $6.0 \pm 1.7$ & & $3.0 \pm 3.5$ & & $4.0 \pm 2.6$ & & & \\
\hline \multirow[t]{2}{*}{ Jousset et al., 2004 (87) } & Neutral & $\begin{array}{l}\text { Pain (VAS/10 } \\
\text { points), function } \\
\text { (QDI), RTW }\end{array}$ & $5.0 \pm 2.2$ & & & & $3.1 \pm 2.5$ & & & \\
\hline & Neutral & & $4.6 \pm 2.2$ & & & & $4.0 \pm 2.8$ & & & \\
\hline $\begin{array}{l}\text { Kankaanpää et al., } 1999 \\
(44)\end{array}$ & Positive & $\begin{array}{l}\text { Pain (VAS), function } \\
\text { (PDI) }\end{array}$ & $54.1 \pm 19.6$ & $42.8 \pm 28.4$ & $36.8 \pm 28.8$ & $44.9 \pm 26.7$ & $35.9 \pm 27.4$ & $46.0 \pm 20.5$ & $28.0 \pm 18.6$ & $44.4 \pm 22.5$ \\
\hline \multirow{3}{*}{$\begin{array}{l}\text { Kendall and Jenkins, } 1968 \\
\text { (71) }\end{array}$} & Unclear & Global & & & & & & & & \\
\hline & Unclear & & & & & & & & & \\
\hline & Unclear & & & & & & & & & \\
\hline $\begin{array}{l}\text { Kuukkanen and Mälkiä, } \\
2000 \text { (72) }\end{array}$ & Neutral & $\begin{array}{l}\text { Pain (VAS/11 } \\
\text { points), function } \\
\text { (ODQ) }\end{array}$ & $1.9 \pm 1.5$ & $1.8 \pm 1.7$ & $1.3 \pm 1.2$ & $1.1 \pm 1.3$ & $1.0 \pm 1.3$ & $1.3 \pm 1.6$ & $1.0 \pm 1.3$ & $1.3 \pm 1.8$ \\
\hline $\begin{array}{l}\text { Lidsträm and Zachrisson, } \\
1970 \text { (73) }\end{array}$ & Unclear & Global & & & & & & & & \\
\hline \multirow[t]{2}{*}{ Lie and Frey, 1999 (74) } & Negative & $\begin{array}{l}\text { Global (COS), } \\
\text { includes pain and } \\
\text { function }\end{array}$ & & & & & & & & \\
\hline & Positive & & & & & & & & & \\
\hline
\end{tabular}




\section{Appendix Table 2-Continued}

\begin{tabular}{|c|c|c|c|c|c|c|c|}
\hline \multicolumn{2}{|c|}{ Initial Functional Impairment } & \multicolumn{6}{|c|}{ Functional Impairment at Follow-up } \\
\hline \multirow[b]{2}{*}{ Ex } & \multirow[b]{2}{*}{ C } & \multicolumn{2}{|c|}{ Short-Term } & \multicolumn{2}{|c|}{ Intermediate } & \multicolumn{2}{|c|}{ Long-Term } \\
\hline & & Ex & $\mathrm{C}$ & Ex & $\mathrm{C}$ & Ex & C \\
\hline $33.3 \pm 17.8$ & $34.7 \pm 17.9$ & $19.1 \pm 19.3$ & $20.8 \pm 17.3$ & $15.1 \pm 17.4$ & $18.4 \pm 17.1$ & & \\
\hline $35.0 \pm 16.9$ & & $20.8 \pm 17.8$ & & $20.9 \pm 17.0$ & & & \\
\hline $48.0 \pm 10$ & & $42.0 \pm 18$ & & & & & \\
\hline $47.0 \pm 14$ & & $43.0 \pm 15$ & & & & & \\
\hline 60.0 & 50.0 & 40.0 & 49.0 & 45.0 & 52.0 & & \\
\hline 55.0 & & 42.0 & & 52.0 & & & \\
\hline 6.5 & 6.9 & $3.2 \pm 3.1$ & $3.2 \pm 3.1$ & $3.5 \pm 4.0$ & $2.5 \pm 4.0$ & & \\
\hline $23.6 \pm 9.7$ & $23.6 \pm 12.3$ & $16.3 \pm 10.3$ & $21.2 \pm 14.2$ & $15.1 \pm 8.3$ & $23.4 \pm 15.2$ & $15.4 \pm 11.3$ & $22.5 \pm 15.4$ \\
\hline $21.12 \pm 11.08$ & $21.6 \pm 11.0$ & $18.47 \pm 9.34$ & $20.27 \pm 9.29$ & $18.23 \pm 11.59$ & $19.8 \pm 10.61$ & $17.85 \pm 10.99$ & $19.4 \pm 11.47$ \\
\hline $24.98 \pm 10.28$ & $36.73 \pm 18.49$ & $21.15 \pm 10.18$ & $38.91 \pm 17.56$ & & & & \\
\hline $17.8 \pm 4.6$ & $16.3 \pm 3.9$ & $6.3 \pm 3.5$ & $6.6 \pm 2.9$ & & & & \\
\hline $15.1 \pm 4.2$ & & $5.5 \pm 3.2$ & & & & & \\
\hline
\end{tabular}

\begin{tabular}{|c|c|c|c|c|c|c|c|}
\hline $5.0 \pm 2.6$ & & $3.0 \pm 3.5$ & & $2.0 \pm 2.6$ & & & \\
\hline $6.0 \pm 5.2$ & & $2.0 \pm 4.3$ & & $1.0 \pm 4.3$ & & & \\
\hline $34.6 \pm 15.4$ & & & & $22.0 \pm 16$ & & & \\
\hline $31.6 \pm 15.9$ & & & & $22.9 \pm 17.7$ & & & \\
\hline $12.3 \pm 10.1$ & $10.1 \pm 7.6$ & $10.4 \pm 11.9$ & $11.6 \pm 10.9$ & $6.1 \pm 5.8$ & $13.3 \pm 10.8$ & $5.3 \pm 8.1$ & $9.8 \pm 9.0$ \\
\hline & & & & & & $0.0 \pm 0.0$ & \\
\hline $17.0 \pm 9.5$ & $14.0 \pm 8.7$ & $10.0 \pm 7.6$ & $11.0 \pm 7.8$ & $8.0 \pm 6.6$ & $12.0 \pm 9.0$ & $6.0 \pm 5.2$ & $10.0 \pm 9.5$ \\
\hline
\end{tabular}




\section{Appendix Table 2-Continued}

\begin{tabular}{|c|c|c|c|c|c|c|c|c|c|c|}
\hline \multirow[t]{3}{*}{ Study, Year (Reference) } & \multirow{3}{*}{$\begin{array}{l}\text { Rating } \\
\text { of } \\
\text { Resultst }\end{array}$} & \multirow{3}{*}{$\begin{array}{l}\text { Outcome } \\
\text { Measures } \\
\text { Reported (Scale) }\end{array}$} & \multirow{2}{*}{\multicolumn{2}{|c|}{ Initial Pain Intensity }} & \multicolumn{6}{|c|}{ Pain Intensity at Follow-up } \\
\hline & & & & & \multicolumn{2}{|c|}{ Short-Term } & \multicolumn{2}{|c|}{ Intermediate } & \multicolumn{2}{|c|}{ Long-Term } \\
\hline & & & Ex & C & Ex & C & Ex & C & Ex & C \\
\hline \multirow[t]{3}{*}{$\begin{array}{l}\text { Manniche et al., } 1988 \\
(26) \ddagger\end{array}$} & Unclear & $\begin{array}{l}\text { Pain (VAS/30 } \\
\text { points), function } \\
\text { (ADL/15 points) }\end{array}$ & $13.3 \pm 4.9$ & & $5.7 \pm 9.4$ & & $5.0 \pm 10.7$ & & & \\
\hline & Unclear & & $14.0 \pm 6.9$ & & $10.3 \pm 9.7$ & & $11.1 \pm 10.8$ & & & \\
\hline & Unclear & & $11.7 \pm 6.1$ & & $9.2 \pm 15.7$ & & $11.5 \pm 8.9$ & & & \\
\hline \multirow[t]{3}{*}{ Mannion et al., 1999 (29) } & Positive & $\begin{array}{l}\text { Pain (VAS/10 } \\
\text { points), function } \\
\text { (RMDQ) }\end{array}$ & $4.2 \pm 1.8$ & & $3.1 \pm 2.1$ & & $2.8 \pm 2.1$ & & $2.9 \pm 2.2$ & \\
\hline & Positive & & $4.1 \pm 1.8$ & & $3.6 \pm 2.5$ & & $3.1 \pm 2.3$ & & $3.2 \pm 2.2$ & \\
\hline & Neutral & & $4.4 \pm 1.8$ & & $3.2 \pm 2.2$ & & $3.2 \pm 2.0$ & & $3.2 \pm 2.0$ & \\
\hline Moseley et al., 2002 (48) & Positive & $\begin{array}{l}\text { Pain (NRS), function } \\
\text { (RMDQ/18 } \\
\text { points) }\end{array}$ & $4.8 \pm 0.0$ & $4.5 \pm 0.0$ & $1.9 \pm 1.5$ & $3.1 \pm 1.5$ & & & & \\
\hline Niemistö et al., 2003 (88) & Positive & $\begin{array}{l}\text { Pain (VAS), function } \\
\text { (ODQ), RTW }\end{array}$ & $60.0 \pm 21.0$ & $53.3 \pm 21.2$ & & & $25.0 \pm 23.0$ & $36.1 \pm 23.3$ & $26.0 \pm 23.0$ & $32.2 \pm 23.3$ \\
\hline \multirow[t]{2}{*}{ Petersen et al., 2002 (49)‡ } & Neutral & $\begin{array}{l}\text { Pain (VAS/60 } \\
\text { points), function } \\
\text { (MRS), RTW, } \\
\text { global }\end{array}$ & $19.0 \pm 13.4$ & & $14.0 \pm 18.1$ & & $17.0 \pm 18.1$ & & $18.0 \pm 14.2$ & \\
\hline & Positive & & $18.5 \pm 13.8$ & & $10.0 \pm 37.8$ & & $13.0 \pm 30.7$ & & $14.0 \pm 31.5$ & \\
\hline \multirow[t]{2}{*}{ Preyde, 2000 (50) } & Neutral & $\begin{array}{l}\text { Pain (PPI), function } \\
\text { (RMDQ) }\end{array}$ & $2.2 \pm 0.7$ & $2.2 \pm 0.8$ & $1.6 \pm 0.8$ & $1.0 \pm 0.7$ & $1.3 \pm 0.8$ & $1.2 \pm 1.5$ & & \\
\hline & Positive & & $2.4 \pm 0.8$ & $2.0 \pm 0.7$ & $0.4 \pm 0.6$ & $1.6 \pm 0.8$ & $0.4 \pm 0.6$ & $1.8 \pm 0.6$ & & \\
\hline $\begin{array}{l}\text { Rasmussen-Barr et al., } \\
2003 \text { (89) } \neq\end{array}$ & Neutral & $\begin{array}{l}\text { Pain (VAS), function } \\
\text { (ODQ) }\end{array}$ & $33.0 \pm 23.53$ & $32.0 \pm 25.0$ & $20.0 \pm 17.65$ & $24.0 \pm 33.82$ & $14.0 \pm 16.18$ & $22.0 \pm 33.82$ & $13.0 \pm 14.71$ & $18.0 \pm 29.4$ \\
\hline Risch et al., 1993 (75) & Positive & $\begin{array}{l}\text { Pain (WHY), } \\
\text { function (SIP) }\end{array}$ & $3.4 \pm 1.6$ & $3.7 \pm 1.6$ & $2.9 \pm 1.7$ & $4.1 \pm 1.5$ & & & & \\
\hline \multirow[t]{2}{*}{ Rittweger et al., 2002 (51) } & Neutral & $\begin{array}{l}\text { Pain (VAS), function } \\
\text { (VAS/70 points) }\end{array}$ & $4.5 \pm 2.2$ & & $1.2 \pm 1.8$ & & & & & \\
\hline & Neutral & & $4.2 \pm 1.9$ & & $1.4 \pm 1.8$ & & & & & \\
\hline \multirow[t]{2}{*}{$\begin{array}{l}\text { Lønn et al., } 1999 \text { (46); } \\
\text { Soukup et al., } 1999 \text { (52) }\end{array}$} & Neutral & $\begin{array}{l}\text { Pain (VAS), function } \\
\quad \text { (VAS) }\end{array}$ & $41.0 \pm 15.0$ & $42.0 \pm 21.0$ & & & $23.0 \pm 16.0$ & $24.0 \pm 17.0$ & $26.0 \pm 19.0$ & $32.0 \pm 23.0$ \\
\hline & Unclear & $\begin{array}{l}\text { Pain (OEP-VAS), } \\
\text { function (VAS/10 } \\
\text { points) }\end{array}$ & $3.5 \pm 18.9$ & & & & $1.8 \pm 15.7$ & & $2.2 \pm 22.0$ & \\
\hline \multirow[t]{2}{*}{$\begin{array}{l}\text { Torstensen et al., } 1998 \\
\text { (31) }\end{array}$} & Neutral & $\begin{array}{l}\text { Pain (VAS), function } \\
\text { (ODQ), RTW }\end{array}$ & $55.0 \pm 21.0$ & & $50.4 \pm 27.2$ & & & & $50.0 \pm 28.0$ & \\
\hline & Neutral & & $53.1 \pm 21.3$ & $50.9 \pm 19.2$ & $37.2 \pm 25.3$ & $39.0 \pm 28.0$ & & & $40.5 \pm 24.4$ & $42.9 \pm 29.5$ \\
\hline \multirow{2}{*}{$\begin{array}{l}\text { Tritilanunt and } \\
\text { Wajanavisit, } 2001 \text { (78) }\end{array}$} & Positive & Pain (VAS) & $5.6 \pm 1.8$ & & $2.3 \pm 1.8$ & & & & & \\
\hline & Neutral & & $5.4 \pm 1.8$ & & $4.0 \pm 1.9$ & & & & & \\
\hline \multirow[t]{2}{*}{ Turner et al., 1990 (79) } & Neutral & $\begin{array}{l}\text { Pain (MPQ), } \\
\text { function (SIP) }\end{array}$ & $19.4 \pm 10.6$ & $21.0 \pm 9.9$ & $17.5 \pm 10.2$ & $17.7 \pm 12.1$ & $15.6 \pm 9.1$ & $19.5 \pm 15.7$ & $14.9 \pm 7.9$ & $16.4 \pm 13.6$ \\
\hline & Positive & & $25.5 \pm 12.4$ & $21.2 \pm 8.8$ & $14.8 \pm 11.4$ & $21.0 \pm 10.6$ & $13.3 \pm 9.1$ & & $18.2 \pm 13.3$ & \\
\hline Yelland et al., 2004 (92) & Neutral & $\begin{array}{l}\text { Pain (VAS), function } \\
\text { (RMDQ/23 } \\
\text { points) }\end{array}$ & $54.6 \pm 19.8$ & $52.3 \pm 20.3$ & $42.0 \pm 26.5$ & $37.0 \pm 45.4$ & $33.0 \pm 26.5$ & $32.0 \pm 30.3$ & $34.1 \pm 28.2$ & $35.8 \pm 30$ \\
\hline \multirow[t]{2}{*}{ Yeung et al., 2003 (93) } & Neutral & $\begin{array}{l}\text { Pain (NRS/10 } \\
\text { points), function } \\
\text { (VAS) }\end{array}$ & $5.88 \pm 1.84$ & & $5.19 \pm 2.47$ & & $5.27 \pm 2.31$ & & & \\
\hline & Positive & & $6.38 \pm 1.77$ & & $3.77 \pm 2.12$ & & $3.46 \pm 2.18$ & & & \\
\hline \multirow[t]{2}{*}{$\begin{array}{l}\text { Yozbatiran et al., } 2004 \\
(94)\end{array}$} & Neutral & $\begin{array}{l}\text { Pain (VAS/10 } \\
\text { points), function } \\
\text { (ODQ) }\end{array}$ & $5.06 \pm 2.28$ & & $2.53 \pm 2.28$ & & & & & \\
\hline & Neutral & & $5.46 \pm 2.19$ & & $1.93 \pm 1.7$ & & & & & \\
\hline \multirow[t]{2}{*}{$\begin{array}{l}\text { Zylbergold and Piper, } \\
1981 \text { (82) }\end{array}$} & Neutral & $\begin{array}{l}\text { Pain (Likert/5 } \\
\text { points), function } \\
\text { (Likert/5 points) }\end{array}$ & $2.3 \pm 1.3$ & $2.9 \pm 0.9$ & $1.3 \pm 0.9$ & $1.4 \pm 0.1$ & & & & \\
\hline & & & & $2.1 \pm 1.6$ & & $1.5 \pm 0.8$ & & & & \\
\hline
\end{tabular}




\section{Appendix Table 2-Continued}

\begin{tabular}{|c|c|c|c|c|c|c|c|}
\hline \multicolumn{2}{|c|}{ Initial Functional Impairment } & \multicolumn{6}{|c|}{ Functional Impairment at Follow-up } \\
\hline \multirow[b]{2}{*}{ Ex } & \multirow[b]{2}{*}{ C } & \multicolumn{2}{|c|}{ Short-Term } & \multicolumn{2}{|c|}{ Intermediate } & \multicolumn{2}{|c|}{ Long-Term } \\
\hline & & Ex & C & Ex & C & Ex & $\mathrm{C}$ \\
\hline $10.3 \pm 5.4$ & & $9.0 \pm 5.7$ & & $5.9 \pm 9.7$ & & & \\
\hline $11.4 \pm 6.6$ & & $8.8 \pm 8.7$ & & $8.3 \pm 8.9$ & & $0.0 \pm 0.0$ & \\
\hline $10.2 \pm 8.3$ & & $8.5 \pm 11.5$ & & $7.8 \pm 9.1$ & & & \\
\hline $8.0 \pm 5.1$ & & $6.7 \pm 5.0$ & & $5.7 \pm 4.8$ & & $5.8 \pm 4.8$ & \\
\hline $7.7 \pm 4.7$ & & $6.3 \pm 5.1$ & & $5.4 \pm 4.4$ & & $6.2 \pm 4.6$ & \\
\hline $7.9 \pm 4.0$ & & $6.8 \pm 4.9$ & & $7.7 \pm 5.3$ & & $7.4 \pm 4.9$ & \\
\hline $29.5 \pm 9.7$ & $28.8 \pm 9.7$ & & & $14.7 \pm 11.6$ & $18.6 \pm 11.0$ & $13.7 \pm 11.6$ & $16.5 \pm 11.6$ \\
\hline $39.3 \pm 16.3$ & & $29.2 \pm 27.3$ & & $34.8 \pm 42.9$ & & $33.3 \pm 28.9$ & \\
\hline $36.7 \pm 18.4$ & & $28.6 \pm 35.2$ & & $26.7 \pm 31.5$ & & $30.8 \pm 36.3$ & \\
\hline $7.2 \pm 5.2$ & $8.6 \pm 4.4$ & $6.8 \pm 5.6$ & $3.4 \pm 2.8$ & $5.7 \pm 4.8$ & $2.9 \pm 3.1$ & & \\
\hline $8.3 \pm 4.2$ & $7.2 \pm 4.2$ & $2.4 \pm 2.8$ & $6.8 \pm 3.5$ & $1.5 \pm 2.0$ & $6.5 \pm 4.2$ & & \\
\hline $18.0 \pm 14.71$ & $14.0 \pm 10.29$ & $9.0 \pm 10.29$ & $12.0 \pm 5.88$ & $6.0 \pm 5.88$ & $13.0 \pm 14.71$ & $8.0 \pm 8.82$ & $8.0 \pm 16.18$ \\
\hline $9.1 \pm 9.3$ & $15.2 \pm 10.4$ & $7.7 \pm 9.4$ & $19.3 \pm 15.6$ & & & & \\
\hline $20.3 \pm 9.9$ & & $10.5 \pm 12.8$ & & $12.0 \pm 12.4$ & & & \\
\hline $20.7 \pm 14.3$ & & $11.6 \pm 11.1$ & & $14.8 \pm 13.6$ & & & \\
\hline $40.0 \pm 20.8$ & $41.0 \pm 51.3$ & & & $60.0 \pm 17.8$ & $61.0 \pm 21.1$ & $58.0 \pm 23.8$ & $52.0 \pm 24.1$ \\
\hline $4.7 \pm 18.9$ & & & & $7.0 \pm 18.9$ & & $6.7 \pm 22.0$ & \\
\hline $50.0 \pm 11.9$ & & $52.7 \pm 16.6$ & & & & $50.6 \pm 16.6$ & \\
\hline $51.7 \pm 10.7$ & $49.4 \pm 10.5$ & $46.2 \pm 13.1$ & $46.9 \pm 13.1$ & & & $44.1 \pm 13.8$ & $43.0 \pm 12.9$ \\
\hline $8.4 \pm 8.2$ & $7.9 \pm 6.4$ & $5.5 \pm 6.8$ & $4.7 \pm 4.1$ & $6.3 \pm 10.1$ & $7.6 \pm 9.9$ & $4.7 \pm 7.8$ & $5.3 \pm 6.7$ \\
\hline $8.5 \pm 4.6$ & $6.2 \pm 5.0$ & $3.6 \pm 3.0$ & $5.4 \pm 5.9$ & $4.5 \pm 4.7$ & & $4.8 \pm 3.4$ & \\
\hline $13.0 \pm 5.1$ & $15.0 \pm 4.3$ & $8.5 \pm 9.5$ & $11.0 \pm 11.4$ & $7.5 \pm 7.6$ & $9.5 \pm 9.5$ & $8.2 \pm 6.7$ & $9.9 \pm 5.9$ \\
\hline $32.49 \pm 13.79$ & & $32.48 \pm 15.31$ & & $25.82 \pm 13.11$ & & & \\
\hline $35.32 \pm 11.72$ & & $20.36 \pm 13.06$ & & $19.86 \pm 10.12$ & & & \\
\hline $38.4 \pm 14.32$ & & $21.06 \pm 12.73$ & & & & & \\
\hline $40.0 \pm 20.14$ & & $20.66 \pm 13.49$ & & & & & \\
\hline $7.3 \pm 3.8$ & $9.8 \pm 6.9$ & $5.2 \pm 1.4$ & $4.7 \pm 7.5$ & & & & \\
\hline & $8.7 \pm 5.4$ & & $5.8 \pm 4.3$ & & & & \\
\hline
\end{tabular}

Continued on following page 
Appendix Table 2-Continued

\begin{tabular}{|c|c|c|c|c|c|c|c|c|c|c|}
\hline \multirow[t]{3}{*}{ Study, Year (Reference) } & \multirow{3}{*}{$\begin{array}{l}\text { Rating } \\
\text { of } \\
\text { Resultst }\end{array}$} & \multirow{3}{*}{$\begin{array}{l}\text { Outcome } \\
\text { Measures } \\
\text { Reported (Scale) }\end{array}$} & \multirow{2}{*}{\multicolumn{2}{|c|}{ Initial Pain Intensity }} & \multicolumn{6}{|c|}{ Pain Intensity at Follow-up } \\
\hline & & & & & \multicolumn{2}{|c|}{ Short-Term } & \multicolumn{2}{|c|}{ Intermediate } & \multicolumn{2}{|c|}{ Long-Term } \\
\hline & & & Ex & C & Ex & $\mathrm{C}$ & Ex & C & Ex & C \\
\hline \multicolumn{11}{|l|}{ Unclear population } \\
\hline Ljunggren et al., 1997 (45) & $\begin{array}{l}\text { Positive } \\
\text { Positive }\end{array}$ & RTW & & & & & & & & \\
\hline
\end{tabular}

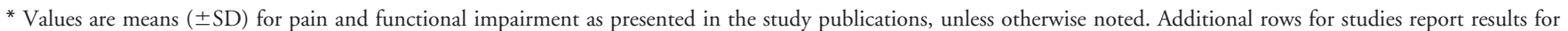

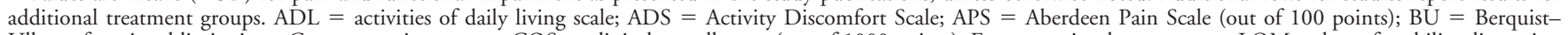

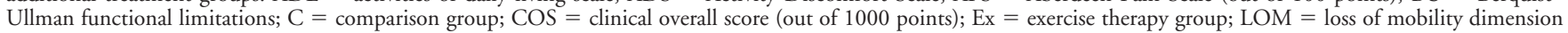

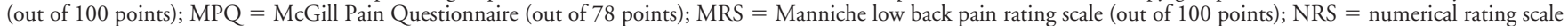

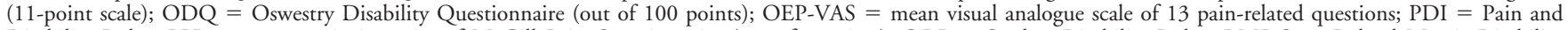

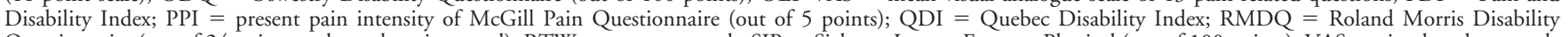

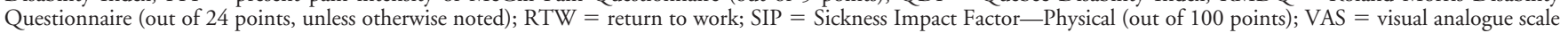
(out of 100 points, unless otherwise noted); WHY = West Haven Yale questionnaire.

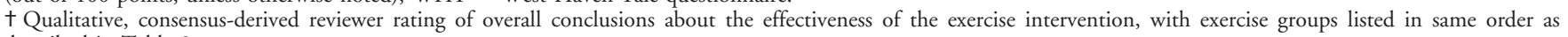
described in Table 2.

$\mp$ Values are median $( \pm S D)$ calculated from the most conservative interquartile range presented.

$\S$ Values presented calculated from rate of change $( \pm S D)$.

$\|$ Galantino et al. (85) was excluded from quantitative syntheses because of flaw: small study with $>50 \%$ loss to follow-up. 
Appendix Table 2-Continued

Initial Functional Impairment

Functional Impairment at Follow-up

\begin{tabular}{|c|c|c|c|c|c|c|c|}
\hline \multirow[b]{3}{*}{ Ex } & \multirow[b]{3}{*}{ C } & \multirow{2}{*}{\multicolumn{2}{|c|}{ Short-Term }} & \multirow{2}{*}{\multicolumn{2}{|c|}{ Intermediate }} & \multirow{2}{*}{\multicolumn{2}{|c|}{ Long-Term }} \\
\hline & & & & & & & \\
\hline & & Ex & C & Ex & C & Ex & C \\
\hline
\end{tabular}

